\title{
International Financial Integration through Equity Markets: Which Firms from Which Countries Go Global?*
}

\author{
Stijn Claessens $^{\text {a } \quad \text { and Sergio L. Schmukler }}{ }^{\text {b }}$
}

\begin{abstract}
This paper studies international financial integration analyzing firms from various countries raising capital, trading equity, and/or cross-listing in major world stock markets. Using a large sample of 39,517 firms from 111 countries covering the period 1989-2000, we find that, although international financial integration increases substantially over this period, only relatively few countries and firms actively participate in international markets. Firms more likely to internationalize are from larger and more open economies, with higher income, better macroeconomic policies, and worse institutional environments. These firms tend to be larger, grow faster, and have higher returns and more foreign sales. While changes occur with internationalization, these firm attributes are present before internationalization takes place. The results suggest that international financial integration will likely remain constrained by country and firm characteristics.
\end{abstract}

JEL Classification Codes: F36, G15, G18, G20

Keywords: international financial integration; internationalization; globalization of financial markets; access to capital markets

World Bank Policy Research Working Paper 4146, March 2007

The Policy Research Working Paper Series disseminates the findings of work in progress to encourage the exchange of ideas about development issues. An objective of the series is to get the findings out quickly, even if the presentations are less than fully polished. The papers carry the names of the authors and should be cited accordingly. The findings, interpretations, and conclusions expressed in this paper are entirely those of the authors. They do not necessarily represent the view of the World Bank, its Executive Directors, or the countries they represent. Policy Research Working Papers are available online at http://econ.worldbank.org.

\footnotetext{
${ }^{\mathrm{a}}$ IMF, University of Amsterdam, and CEPR ${ }^{\mathrm{b}}$ World Bank

* A previous version of this paper was circulated as "Accessing International Equity Markets: Which Firms from Which Countries Go Abroad?" We would like to thank seminar participants at CERGE Prague, Erasmus University, the ESRC Macro, Money, and Finance workshop (London), HEC, Indiana University, INSEAD, the Santa Cruz Center for International Economics at UC Santa Cruz (Conference "Financial and Commercial Integrations"), University of Amsterdam, University of Salerno, and Yale University, and our discussant Galina Hale and editors Joshua Aizenman, Jim Lothian, and Brian Pinto for very useful comments. We are especially grateful to Jose Azar, Francisco Ceballos, Tatiana Didier, Juan Carlos Gozzi, and Ying Lin for their excellent research assistance at different stages of the process. For help with getting the data, we thank Pamela Dottin, Dori Flanagan, Angela Marshall, Richard Webster-Smith, and Cheryl Workman. For financial support, we are grateful to the World Bank Research Support Budget. The paper was completed while the first author was at the World Bank. Contact information: Stijn Claessens: sclaessens@imf.org; Sergio Schmukler: sschmukler@worldbank.org.
} 


\section{Introduction}

Financial globalization has increased significantly during the last decade. The increased integration of financial systems has involved greater cross-border capital flows, tighter links among financial markets, and greater presence of foreign financial firms around the world. Indeed, many of the standard aggregate measures of financial globalization such as gross capital flows, stocks of foreign assets and liabilities, and degree of co-movement of returns suggest that international financial integration has become widespread and has reached unprecedented levels. ${ }^{1}$ Although these measures offer very useful insights on an aggregate basis, they provide less evidence on how extensive financial integration is, how deep it reaches, and how it comes about. For example, these measures do not tell how many firms from how many countries are actively participating in this integration process, what proportion of the corporate sector actually internationalizes, or, even more important, why firms seek to internationalize.

In this paper, we complement the existing literature by studying the extent of international financial integration analyzing firms' activity in world equity markets. To do so, we compile new data, dividing firms into "international firms" (those that participate in international stock markets by raising capital, cross-listing, and/or issuing depositary receipts in global markets) and "domestic firms" (all other firms). ${ }^{2}$ With these data, we study how the participation of firms in major world stock exchanges is related to country and firm characteristics. This way, we are able to address several important questions. Does the intensity of the internationalization process mean that firms from all countries use international capital markets? From which countries are firms more likely to participate in international equity markets? For those countries that see some degree of internationalization, how extensive is this process? Do country characteristics matter for the degree of internationalization? If so, which ones? Within the countries that internationalize, is it a specific subset of firms that participates in international capital

\footnotetext{
${ }^{1}$ For a historical perspective on globalization, see for example Baldwin and Martin (1999), Bordo et al. (1999), Lothian (2002), and Obstfeld and Taylor (2004). A comprehensive overview of the main operational measures of financial integration is provided by Obstfeld and Taylor (2002) and Kose et al. (2006), among others.

${ }^{2}$ As a complement to this study, see Hale and Santos (2005) and Hale (2006) for an analysis of firm issuance of bonds and loans in the international financial system. For price measures of equity market integration see, for example, Levy Yeyati et al. (2006) and references therein.
} 
markets? Are the characteristics of firms that internationalize different ex-ante from those that do not?

While the analysis in this paper tries to identify important facts regarding the extent of international financial integration using firm-level data, the evidence presented also sheds light on some other debates taking place in the literature. Of particular interest to this paper is the literature that studies the interaction between country-level (macroeconomic) and firm-level (microeconomic) factors and firm participation in international equity markets.

At the country level, there is by now consensus that there is a strong relation between domestic stock market development and macroeconomic factors (see Levine 2005 for a review); however, there are different views on how macroeconomic variables relate to firms' activity in international equity markets. From one standpoint, it is argued that worse macroeconomic conditions increase the need and desire to use international markets. Poor domestic environments have long been considered one of the main reasons for capital flight and greater use by domestic residents and firms of all types of financial services offered internationally. The literature on "bonding" specifically argues that international markets are more attractive to firms from countries with weak institutional environments since they offer the ability to "bond" firms to a system that better protects investor rights. ${ }^{3}$ Thus, worse fundamentals may hinder the development of domestic markets, but increase the use of international markets. From a different perspective, better domestic environments can increase the attractiveness of firms to investors, especially foreign ones. Foreign investors who have the ability to invest globally will generally offer larger amounts of external financing and lower cost of capital as firms' host country fundamentals improve. By listing abroad, a firm only adds to this tendency. Therefore,

\footnotetext{
${ }^{3}$ See Benos and Weisbach (2004) for a review of this literature. One of the first papers in this literature is Coffee (1999), who argues that cross-listing in an exchange with better investor protection is a form of bonding, creating a credible and binding commitment by the issuer to protect the interests of minority shareholders. Reese and Weisbach (2002) find that, after cross-listing in the U.S., firms from countries with a weaker corporate governance framework are more likely to issue consecutively equity at home. They argue that this is because cross-listing improves investor protection for all shareholders, including those outside the U.S. There are, however, skeptics of the bonding view. Licht (2003) and Siegel (2005), for example, find that the host regulators typically provide only limited protection against minority rights abuses by controlling shareholders in the firm's home country, and thus the value from bonding is limited.
} 
under this view, better domestic fundamentals lead to more (not less) use of international capital markets.

These two views on internationalization have quite different predictions. Under the first view, firms choose to go abroad and in doing so escape, at least partially, a poor domestic environment. Under the second view, however, firms from good environments are the ones that tend to go to global markets, as the suppliers of capital grant them access to international markets at attractive enough terms. ${ }^{4}$ In practice, it is hard to pin down the relative importance of these two views, i.e., the relative role of demand side and supply side factors that make (and allow) firms to go abroad. But that has not deterred recent research to start shedding light on several aspects of this debate.

At the microeconomic level, papers have studied the firm-level factors related to the participation of corporations in international capital markets. Similar to going public, there are many potential benefits of going from developing capital markets to the more developed global markets. Firms can attract capital at lower costs and better terms, tap into wider investor bases, and end up with more liquid securities. In fact, several papers find that firms that participate in international capital markets tend to obtain better financing opportunities, de-leverage, extend their debt maturity, and grow faster. ${ }^{5}$ Trading abroad may also enhance liquidity domestically and affect price discovery. ${ }^{6}$ Other recent research argues that by going abroad and thus committing to higher standards of corporate governance and/or disclosure, firms reduce their cost of capital, both for local and international raisings (for example, Cantale, 1996, Fuerst, 1998, and Doidge et al., 2004).

While most papers find that internationalization yields some benefits to firms, thus confirming some of the arguments above, the analysis regarding which firm

\footnotetext{
${ }^{4}$ Other aggregate factors also matter. For example, Sarkissian and Schill (2004) find that geographical proximity and affinity factors, such as trade links and common language, explain cross-listing for a large sample of firms from many markets. Diversification gains seem to matter little as cross-listing is more (not less) common across markets where returns are highly correlated.

${ }^{5}$ See, for example, Baker et al. (1999), Chaplinsky and Ramchand (2000), Miller and Puthenpurackal (2002), Lins et al. (2005), Gozzi et al. (2006), and Schmukler and Vesperoni (2006).

${ }^{6}$ Kadlec and McConnell (1994), Noronha et al. (1996), Smith and Sofianos (1997), and Foerster and Karolyi (1998) find that competitive pressures from other exchanges and greater turnover associated with wider shareholder bases can narrow domestic spreads and raise trading activity. Grammig et al. (2005) show that liquidity is an important factor in determining where price discovery takes place (at home or in international markets). Foucault and Gehrig (2006) show that cross-listing allows firms to make better investment decisions because it enhances stock price informativeness.
} 
characteristics matter ex-ante for internationalization has been scarcer. ${ }^{7}$ Various firm attributes may affect the probability of participating in international markets. Firm size might play an important role to the extent that there are significant fixed costs to accessing international markets. These fixed costs can derive, for example, from the need to comply with international accounting standards and/or the minimum market capitalization requirements to list abroad (Saudagaran, 1988). Growth opportunities may matter as firms with large unrealized growth opportunities might be more likely to go to more developed global markets (Bekaert et al., 2006). Since firms with foreign sales can pledge foreign revenues as a form of international collateral, they may be able to relax their borrowing constraint by accessing international capital markets (Caballero and Krishnamurthy, 2001, 2002). Also, to the extent that international equity markets are more developed than domestic ones, firms with high returns on capital might be more likely to seek equity capital abroad. Finally, corporate governance measures might be indicators of the willingness of firms to go to international markets and comply with stricter investor protection regulations (Doidge et al., 2006). Depending on what specific reasons motivate firms to access international equity markets, certain firm characteristics can thus be expected to relate to the probability of going abroad.

To analyze the participation of firms in international equity markets and its relation to country and firm characteristics, we compile a large sample of 39,517 firms from 111 countries covering the period 1989-2000. Of these firms, 2,546 are international firms, accounting for a maximum of 30,552 firm-year observations. The remaining 36,971 domestic firms account for a maximum of 223,740 firm-year observations. For each firm we collect a set of firm-level information, such as size, growth, performance, and foreign trade activity. We also compile aggregate country information related to domestic stock market development, internationalization, and other commonly used country attributes.

We start by conducting the analysis at the country level. This helps to understand how widespread internationalization across countries is and how country characteristics relate to internationalization. Then, the analysis at the firm level involves, besides a

\footnotetext{
${ }^{7}$ A notable exception is Pagano et al. (2002), who study the characteristics of European firms listing abroad. They find that firms with high growth (potentials) and in high-tech industries are more likely to list in the U.S.
} 
description of the firms that access international markets, estimations of the probability of firms becoming international, using cross-sectional and panel estimations. These estimations help to identify whether international firms have some common, distinguishable features relative to firms listed only in the domestic market. Finally, we compare the evolution of firm characteristics over time. These comparisons are useful to understand to what degree differences between international and domestic firms exist even before internationalization and how firm characteristics change over time, along the internationalization process.

The analysis shows that only a relatively small fraction of countries and firms use international markets. The firms more likely to go abroad are located in certain countries, specifically in those with bigger economies, higher income levels, and better macroeconomic, but worse institutional environments. International firms themselves tend to be larger, grow faster, have higher rates of return and have more foreign sales. In other words, the firms that internationalize tend to be drawn from a particular group of countries and seem different from other firms. The results suggest that certain characteristics related to countries and firms are important factors in the internationalization process, suggesting that it might be difficult for many firms to participate directly in international capital markets.

The analysis in this paper improves over related previous work. The dataset of firms, countries, and observations is very comprehensive and allows for a relatively complete study of the integration of capital markets at the firm level. By employing a large and diverse number of countries and firms over various years, the analysis characterizes well both country- and firm-level factors related to the likelihood of using international equity markets. Therefore, relative to the papers that use only country-level information or microeconomic data for a small set of countries, our analysis sheds light on which (including how many) countries and firms are able to capture the gains from internationalization. Moreover, the paper tests the importance of both macroeconomic and microeconomic variables in the process of going abroad. Additionally, the analysis captures a broader process of internationalization than before by including access to more than one international stock exchange and different forms of internationalization (capital raising, issuing, and trading). The period under study is also interesting because it 
comprises 12 relevant years, when many developing countries introduced reforms (including opening up their financial systems), which was followed by years of high internationalization (up to the burst of the dotcom bubble). ${ }^{8}$ In sum, we are able to analyze an important aspect of international integration using a new and large dataset of firms across countries, within countries, and over time. This contributes to new insights into both what type of countries have firms that go abroad and what type of firms access international markets.

The rest of the paper is organized as follows. Sections 2 and 3 describe the data and methodology. Sections 4 and 5 respectively present country- and firm-level summary statistics and results on the extent of internationalization. Section 6 concludes.

\section{Data}

To perform our empirical analysis, we compile a comprehensive database of internationalization and collect data on the characteristics of internationalized firms as well as of those firms that remain domestic, which we use as a control sample. We assemble data on firms' participation in the international equity markets as well as in the local markets for a total of 111 countries for the period 1989-2000. Details on the data collected and the specific variables are summarized in Appendix Table 1, while the list of countries covered and the groupings by income level are provided in Appendix Table 2.

As international financial markets, we mainly study the two largest financial centers, New York and London, but we also use data from the Frankfurt Stock Exchange. There are no comprehensive data available on the degree to which securities are being listed and traded abroad. We therefore combine a number of sources on international activity, four for international trading activity in the U.S. and two for in Europe.

For the U.S., the first source is the Bank of New York, which covers depositary receipt (DR) programs in the three major stock exchanges in the U.S.: NYSE, NASDAQ, and AMEX and contains information on the list of current DR programs and the effective date of each program. As of March 2005, there were a total of 2,259 listed programs. The DR Directory includes all currently active programs, dating back to January 1956, with most of them after 1980. The resulting database accounts for 1,990 firms with active DR

\footnotetext{
${ }^{8}$ See de la Torre et al. (2006).
} 
programs in 80 countries. The second database is NASDAQ, which covers data on foreign companies listed on that stock exchange since 1989. In addition, a third dataset is from NYSE and has data on foreign companies cross-listed on NYSE. The fourth source for the U.S. is Euromoney, which covers all operations of capital raised in international markets by firms. This database provides a comprehensive account of capital raised, because it includes DR programs, cross-border listings, and capital raised in equity markets around the world. The database we obtained reports 8,795 operations from 5,665 firms in 86 countries during January 1983 - April 2001.

To cover international activity in Europe, we use a dataset from the London Stock Exchange (LSE) that contains information on international activity for firms from 63 countries from January 1997 on. The second dataset comprises international activity on all German stock exchanges and is provided by the Frankfurt Stock Exchange (FSE). It covers international firms for 68 countries for 1999 and $2000 .^{9}$

The data from Bank of New York, Euromoney, NYSE, NASDAQ, LSE, and FSE allow us to construct the list of international companies. Precisely, we define international firms as those that cross-list directly, have their equity traded in the form of DRs, or raise capital in international stock markets. Our definition is thus more general than just listing on international exchanges, because it also captures capital raising without listing. We do not consider, however, the degree to which foreign investors hold shares or trade in local markets as an indicator of internationalization. It would not be possible to construct such a series on a consistent cross-country basis because most countries do not distinguish between local and foreign investors in their domestic markets. We also limit ourselves to only three financial centers, and thus do not consider firms that cross-list in any other (developed) country to be international. Furthermore, although there are some firms during the period that are no longer international, i.e., do no longer have an ADR program or are no longer cross-listed, we neither study this aspect (nor do we expect it to influence our results as exit is fairly limited over the period studied).

\footnotetext{
${ }^{9}$ Since the time series available for the Frankfurt data are much shorter, we do not classify firms as international if they internalize only through FSE, the reason being that we cannot pinpoint the exact timing of internationalization. Instead, we use the FSE data to remove firms from the pool of domestic firms.
} 
We next gather macroeconomic and other country information, including variables related to macroeconomic policies and country-level indicators related to their economic and financial development. The country variables used are mainly from the World Bank's World Development Indicators, except for the indexes on financial liberalization and institutional environment (see Appendix Table 1 for details). Additionally, we collect information from Worldscope on firm characteristics, including information on balance sheet and income statements, for all listed firms in the local markets.

\section{Methodology}

To investigate the macroeconomic and microeconomic factors related to the use of international equity markets, we start from earlier work at the country level (Claessens et al., 2006), where we show that a number of country fundamentals matter for the aggregate international stock market activity. We employ these country fundamentals here as well. Specifically we use: GDP in U.S. dollars, GDP per capita, inflation, fiscal surplus, and trade openness (exports and imports relative to GDP). For the institutional environment, we use indexes on the country's degree of financial openness, law and order, and degree of investor protection. ${ }^{10}$

For the microeconomic factors, we work with a standard set of firm characteristics used in the literatures on internationalization and going public decisions. The ones we employ can be thought to fall under four headings: size, growth, performance, and international activity. As proxy for firm size, we use total assets (we also used number of employees and total sales revenue, which led to similar results). As growth characteristics we employ growth in total sales revenue. For performance we use return on assets. As a proxy for firm's international real activity we employ the share of foreign sales over total sales. Finally, we also use the sector in which the firm is mainly active. $^{11}$

\footnotetext{
${ }^{10} \mathrm{We}$ also used some other country level variables, including the development of the local financial markets and the degree of cross-border equity flows. Including these variables does not change the qualitative results for the country variables we do include and report here. At the same time, these variables may be endogenous to internationalization, so there are reasons for not using them.

${ }^{11}$ We also employed a number of other variables, such as the growth in the number of employees, assets per employee, research per employee, research over revenue, property, plant, and equipment growth, price-
} 
We employ different techniques, building mainly on those used by Pagano et al. (1998) to analyze the going public decision and by Pagano et al. (2002) to analyze the going abroad decision of firms. Each technique responds in part to a different question and to the use of country- or firm-level information.

At the country level, we differentiate countries by the degree of their international activity and study how the macroeconomic factors listed above relate to the internationalization process. In particular, besides providing descriptive statistics, we conduct median equality tests to see whether countries that experience more (or any) internationalization have characteristics different from those that experience less (or no) internationalization.

To further investigate which country characteristics relate to the propensity of firms to go abroad (the share of international firms out of the total number of listed firms), we estimate random-effects (linear) panel and Tobit models, using the same country characteristics as those used for the descriptive statistics. The Tobit estimator takes into account the nature of the dependent variable, which could be censored at zero. We estimate different specifications to test the robustness of the results to the inclusion of different variables and to sample variations. We also compute the same estimations but using separately developed and developing countries to see if the results are mainly driven by variations across income groups or whether the same patterns hold. Finally, as an alternative technique, we estimate fixed-effects panel regressions. ${ }^{12}$

At the firm level, we try to identify the characteristics of firms internationalizing. As summary statistics, we compare the differences in medians between international and domestic firms for a set of firm characteristics. We do this in two different ways. First, we compare the characteristics of domestic versus international firms, for the whole

to-earnings ratio, price-to-book value, leverage, short-term debt to total debt, retained earnings, and capital expenses over total assets. We do not report these variables, but the analysis using these variables shows that they can be thought as close proxies for the ones we do report. We do not have access to corporate governance data at the level of individual firms to investigate the role of corporate governance in firms' internationalization decisions.

${ }^{12}$ We do not estimate fixed-effects Tobit models because of the lack of consistent estimators. We also tried to estimate Heckman models to account for the possibility that countries that do not have any internationalization are inherently different, with this difference not fully accounted for by the explanatory variables used in the main equation. It turned out to be difficult to find variables that could be used in the first stage, Heckman selection equation, but that should not be used in the main equation. The specifications we did try (but not report) were generally supportive of the results reported here, although statistical significance in the main equation was typically less prevalent. 
sample and for the groups of developed and developing countries separately. Second, we compare whether international (and domestic) firms are different across developed and developing countries.

To investigate which firm attributes help predict internationalization, we next estimate Probit and Cox proportional hazard models. The Probit estimator predicts the going abroad decision over a future time period using information as of a certain early date; namely, it does not use new information (for prediction purposes) becoming available at any time period after this initial date. This is thus a conservative way of identifying firm characteristics driving internationalization (e.g., as it is not affected by firms preparing for internationalization, or changing some of their attributes).

The Cox model also estimates the determinants of the probability of internationalization, but uses all the available information up to the year before internationalization. The model relates the hazard rate $h(t)$ (the probability of internationalization at time $t$ conditional on not having become international yet) to a set of observable variables $X: h(t)=h_{0}(t) \exp \left(X^{\prime} \beta\right)$, where $h_{0}(t)$ is the baseline hazard rate at time $t$ for the covariate vector set at $O$ and $\beta$ is a vector of coefficients. This semiparametric estimator assumes that the hazard ratio $h(t) / h_{0}(t)$ is constant over time and requires no assumptions about the baseline hazard.

As the set of firm explanatory variables for the Probit (Cox) model, we use the initial (previous year's) values of the logarithm of total assets, the logarithm of sales growth, the return on assets, and the proportion of sales abroad. For the Cox model, if a firm internationalization takes place any time between January and December of year $t$, the firm-level explanatory variables are values for December of year $t-1$. We include sector dummies to control for industry specific effects. We also include time dummies in the Cox model to account for any time-specific factor affecting the likelihood of becoming international. We control for country factors driving the internationalization choices in one of two ways: we either include individual country dummies, or we include the same country characteristics as used in the basic country-level regressions (GDP, GDP per capita, inflation, stock market liberalization, trade, and investor protection). As above, we report estimates for the whole set of firms and for the firms from developing countries only. 
Lastly, we conduct regressions with the key firm characteristics as dependent variables and using simple dummies for before and after internationalization at the level of the individual firms as independent variables. We use these regressions to find the (statistically significant) differences between international and domestic firms before firms internationalize and to find any differences between international and domestic firms after their internationalization. These regressions control for industry, country, and year effects using additional dummy variables. The coefficients on the before dummy tell whether international firms are different from domestic firms before they internationalize; the after dummy tells whether international firms are different from domestic firms after becoming international. Both dummies also allow to test whether there are differences among international firms before and after internationalization.

\section{Internationalization: country-level perspective}

This section focuses on the country-level stylized facts, showing first some descriptive statistics. Figure 1 plots the time series of the total number of firms that become international each year, the market capitalization of all international firms relative to total market capitalization, and the share of value traded internationally relative to value traded domestically. The charts show these indicators split by developed and developing countries. The number of new international firms relative to the number of listed firms shows a strong upward trend period for the group of developed countries and a moderate increase which then tapers off for the group of developing countries. Not surprisingly, the number of companies going abroad is higher for developed countries compared to developing countries during most of the sample period. It also shows that for firms from developing countries, the time pattern for internationalization is more volatile. For developing countries internationalization increases significantly at the beginning of the sample period, peaking in 1994 at 170 firms annually, and then tapers off substantially to below 80 new firms annually. This in part reflects the pattern of privatization in those countries. Contrary to this, internationalization for firms in developed countries takes off in the mid 1990s and almost doubles between 1998 and 2000 from 108 new international firms to 190 firms annually. 
The ratio of market capitalization of international firms to total market capitalization shows from another perspective the internationalization trend, especially for developed countries. For developed economies, the ratio of market capitalization of international firms to total market capitalization increases from less than 20 percent in 1989 to 47 percent in 2000 . For developing countries, the ratio of foreign to total market capitalization also increases, but from a much lower base and ends up at 19 percent.

Somewhat similar trends are present for the value traded abroad relative to value traded domestically, but in this case there is a more pronounced increase for developing countries during the 1990s and a relatively slower increase for the group of developed countries. The average trading ratio rises from a few percentage points to 52 percent in 1996 for developing countries; and at the end of the period, 29 percent of trading takes place abroad, on average, for these countries. For developed countries, the average ratio of trading abroad to home trading rises from 15 to 28 percent over the same period. ${ }^{13}$

We next provide some basic summary statistics by region and income on the importance of internationalization. ${ }^{14}$ For the year 2000, Table 1 presents the total number of countries covered (column 1), the number of countries with active stock markets (column 2), the number of countries with some internationalization (column 3), and the share of countries with some internationalization (column 4, which is simply column 3 divided by column 2). ${ }^{15}$ It shows that about 63 percent of countries have some degree of internationalization of their equity markets, with the share of countries with international activity the highest for developed countries at 76 percent. Otherwise, no strong regional or income differences exist in this measure.

Next, Table 1 provides the number of domestic firms listed (column 5), the number of international firms (column 6), and the share of international firms out of the whole sample of domestic firms covered for each region (column 7, which is column 6

\footnotetext{
${ }^{13}$ This number may underestimate the degree of internationalization, however. While we have data on trading in ADRs and GDRs (the main vehicle used for internationalization by firms from low- and middleincome countries), we do not cover trading in cross-listed stocks (a vehicle more typically used by firms from high-income countries). In our dataset, 45 percent of international firms cross-list or raise capital in a public exchange, while ten percent use ADRs/GDRs.

${ }^{14}$ Appendix Table 2 provides the total number of firms, distinguished by domestic and international firms, covered for each country. The sample of domestically listed firms does not cover all firms within the country, mainly since we needed to collect a variety of firm-specific indicators that are not available for the whole array of domestic firms.

${ }^{15}$ For the ratios, the table provides the average of the within group ratios, not the ratio of the averages.
} 
divided by column 5). The table shows that about 2,500 firms of around 37,000 firms in our sample are international, or, on average, about seven percent of firms, with a high of 15 percent for Latin America, followed by 12.7 percent for developed countries, and a low of two percent for Central and Eastern Europe. Note that, on the one hand, these ratios can overstate internationalization as we do not have a complete coverage of all domestic firms listed, but rather just use the domestic firms listed on the main stock market. ${ }^{16}$ On the other hand, we do not cover internationalization into all financial centers, so the degree of internationalization can also be underestimated.

In terms of sectoral composition, most international firms are from the manufacturing, services, and finance sectors (see Appendix Table 3). Firms active in transportation and public utilities, public administration, and services see more peers migrate. Many international firms in developed countries come from the manufacturing and services sector, while in developing countries many firms come from the manufacturing, finance, and utilities sectors. Otherwise, there are no strong sectoral trends.

We also consider the degree of internationalization in terms of market capitalization and value traded of domestic and international firms, and the corresponding relative amounts (Table 1, lower panel). The figures on market capitalization make clear that firms internationalizing tend to be larger as the share of market capitalization represented by international firms (28 percent) exceeds the share in numbers (seven percent). In terms of value traded, the share of value traded abroad (18 percent) exceeds the share in number, showing that international firms are more heavily traded abroad than domestic. There are large regional variations, however. For developed countries, firms representing some 47 percent of market capitalization are internationalized; this is only 9.5 percent for Africa, however. Variation in the degree of trading abroad is even larger. Whereas for Latin America trading abroad is 61 percent of trading domestically, for most other regions, this share is less than two percent (except for the developed countries, where it is 28 percent). Of course, domestic market capitalization and value traded vary a great deal among countries, even relative to the size of their economies. Total market

\footnotetext{
${ }^{16}$ The sample of domestically listed firms does not cover all firms within the country, mainly because we use several data sources for these firms (which restrict the sample) and there can be multiple listing outlets.
} 
capitalization of Eastern European firms, for example, amounts to only 11 percent of these countries' GDP, compared to 109 percent for developed countries. As such, the internationalization of a few firms can have a greater impact when domestic stock markets are less developed.

The fact that a relatively small number of countries and firms internationalize can be shown by depicting over time the proportion of countries with some fraction of international firms and the proportion of international firms relative to domestic firms worldwide (Figure 2, top panel). The top line of the figure shows that there is a steady increase in the number of countries with some internationalization, with about 70 percent of countries having at least one international firm by the end of the sample period. But, when considering the degree of internationalization at the country level (the bottom line in the figure) the picture is more nuanced: the proportion of countries where the fraction of international firms is more than ten percent also rises over the period, but only reaches some 32 percent at the end of it. The lower panel of the figure shows the trend in the proportion of firms internationalizing. It shows a similar steady, but again selective, increase in internationalization. Out of the whole sample of firms, the proportion of international firm rises from three to seven percent over the period (these proportions are very similar when we average the fractions by country observations). Together, these two figures show that internationalization still remains limited to a small group of firms and countries.

In general, internationalization is not evenly spread across countries. Figure 3 provides the distribution of countries ranked by three indicators: the number of firms that are international relative to the number of domestic firms, the share of market capitalization of international firms relative to total market capitalization, and the share of value traded international relative to total value traded. It shows again that, in 2000 , there are many countries for which there is no or little internationalization, with fewer than ten percent of firms being international in almost 66 percent of the countries.

Figure 3 also reinforces the point that the average international firm is typically much larger than the average domestic firm, as the bars for the share of market capitalization of international firms relative to domestic firms lie much above those for the share of the number of international firms relative to domestic firms. For example, 
while for the $4^{\text {th }}\left(5^{\text {th }}\right)$ quintile on average ten $(30)$ percent of firms are international, the share of market capitalization of international firms for the $4^{\text {th }}\left(5^{\text {th }}\right)$ quintile is on average 44 (71) percent, showing that the average international firm is much larger than the average domestic firm.

For trading abroad versus domestic, a different pattern exists across countries, as also shown in Figure 3. For most countries, trading is less likely to be undertaken internationally than listing or capital raising are, as the bars for the ratio of trading abroad are lower than those for the number of firms and market capitalization shares of international firms. For the $5^{\text {th }}$ quintile, international trading amounts on average to 51 percent of domestic trading, above the share of number of firms but below the share of market capitalization for that quintile. Yet, the line becomes steeper at the high end, with some countries having trading abroad relative to domestic trading exceeding 100 percent.

The comparisons already suggest that there are large country differences in internationalization. We next analyze how country characteristics relate to the degree of internationalization. Before discussing the results, it is worth stressing that there exist high correlations among many country variables, and as such it is not necessarily any specific country variable that explains the degree of internationalization.

We start with some simple summary statistics, distinguishing countries that have no international activity from those countries that do (Table 2.a, top panel). The table shows that countries with international activity are generally larger and have higher income per capita than those countries that have no international firms. With respect to macroeconomic policies, the results are mixed. While countries with international activity appear to show lower inflation rates, they also tend to show lower fiscal surpluses. Countries that have internationally active firms are more open financially and have better law and order and investor protection, although the differences are not statistically significant. Countries with internationally active firms engage less in trade, however. They suggest that more developed countries see more internationalization.

The next panel in Table 2.a considers the same differences between the bottom and top 20 percent of countries, where the ranking is done on the basis of the share of market capitalization abroad. The pattern here is similar as that for the differences between countries with and without international activity: those countries that have the 
highest degree of internationalization tend to be the larger and richer countries, have better inflation, but somewhat worse fiscal management, are more open to financial flows, have less trade in goods and services, and have better law and order and investor rights. All differences are statistically significant at least at the five percent level.

These comparisons remain largely the same when sorting countries by the share of value traded abroad or by the share of number of firms listed abroad (Table 2.b). These comparisons again show that the countries with the most internationalization are larger, have higher income, and are more open in their financial flows and less open in trade. The only difference is that the group of countries in the bottom 20 percent of countries in terms of relative number of international firms displays a slightly lower ratio of trade to GDP than the top 20 percent of countries does, but the difference is small (a ratio of 0.74 versus 0.73 ) and that some of the differences on the institutional environment indexes are no longer statistically significant.

Since many of the country variables are highly correlated, the pair-wise comparison might change when using multivariate analyses. We therefore next present different estimates of the relation between country factors and the degree of internationalization, measured as the ratio of international firms over all firms. The same country variables as those in Table 2 are used as explanatory variables. We first conduct the estimations with few independent variables allowing for a larger set of countries. We then consider more independent variables which reduces the set of countries. We use both random-effects panel and Tobit regressions, where the latter takes into account the fact that some countries do not have any international firms.

Results for all countries are reported in Table 3.a. for both the larger and smaller set of countries. Here we consistently find that the larger the country, the higher its income, and the more stable its macroeconomic management, the higher the degree of its internationalization. Also the more open its trade and the more open it is financially, the more internationalization it experiences. And, for the smaller set, countries that have better investor protection and better law and order have less internationalization, although the coefficients for these indexes are not always statistically significant, probably due to the high correlation with the other macro variables. The findings from the simple comparison that countries that are less open in trade see more internationalization is thus 
not confirmed. This could be because the regressions include other country characteristics, such as the level of income, that are positively related to trade openness. And trade and local financial development are related. Rajan and Zingales (2003), for example, find a positive relation between trade openness and financial market development. The fact that countries that have better investor protection and better law and order have less internationalization may be explained by the idea that, again conditional on general development, firms in countries with lower levels of legal development try to go international to bond to higher standards. Tobit regression results show larger and a few more statistically significant coefficients than the panel ones. Otherwise, there are no qualitative differences between the panel and Tobit regression results, suggesting that the censoring of the data at zero does not affect the overall conclusions.

We next focus on developing countries to test whether the set of developed countries with more internationalization is driving our results. The results are not different (Table 3.b). The exception is the coefficient for law and order, which becomes consistently statistically significant in both the panel and Tobit models. Some of the coefficients are also larger in magnitudes. This could reflect that internationalization for developing countries is much more driven by country characteristics. The result nevertheless shows that no particular group of countries drives the overall relationships. ${ }^{17}$

The general conclusion from the country-level analysis is that more developed countries that have better macroeconomic fundamentals, trade more, and are more open financially tend to see more internationalization, whereas countries that have better institutional environments see less internationalization. This is consistent with other research work (Claessens et al., 2006). It confirms the view that generally better domestic fundamentals lead to more (not less) use of international capital markets, thus supporting

\footnotetext{
${ }^{17}$ We also conducted fixed effects panel estimations that serve as robustness tests and which are reported in Appendix Table 4. The set of regression results for all countries (upper panel) confirms most, although not all of the findings of the panel and Tobit regressions. The major exception is that the coefficients for GDP per capita are different in sign, that is, negative. This is likely because using fixed effects at the country level already controls for country differences, of which GDP per capita is the most important indicator. The negative sign for GDP per capita then rather refers to the effect of time-variation in GDP per capita on internationalization, with growing economies observing less internationalization. In a few cases, coefficients are no longer statistically significant (mostly those for fiscal surplus and stock markets liberalization), while sometimes coefficients are significant when they were not before. Results using the set of developing countries only (lower panel) confirm the results for all countries.
} 
the hypothesis that international investors' demand factors play an important role in the ability of firms to go international. But it also shows that some institutional factors, particularly related to the quality of the legal system, can make firms seek internationalization more.

The country estimates seem economically significant. Using the regression results of the first specification of Tables 3.a and 3.b, a one percent increase in the country's GDP and GDP per capita would result in an increase in the proportion of international firms to total firms of about three and four percentage points respectively, in case of the panel estimations, and about six and two percentage points, in case of the Tobit estimations. ${ }^{18}$ And a one percent rise in inflation would result in a ratio of two and six percentage points lower, for the panel and Tobit regressions, respectively. For the variables that are not in logs, the effects can best be interpreted using changes in standard deviation. A one standard deviation increase in the stock market liberalization index would result in an increase in 0.7 and 2.3 percentage points for the panel and Tobit estimations respectively, and a decrease of one standard deviation in trade to GDP would result in a 4.5 percentage point increase for both estimation methods in the ratio of international firms. In the case of the institutional variables, the effect is quite the same for the panel estimations, with a decrease of ten percentage points after an increase of one standard deviation in any of the indices. For the Tobit estimations this effect is reduced to roughly two percentage points in the case of the investor protection Index. ${ }^{19}$ For developing countries, these magnitudes are very similar to those obtained using the whole sample of countries.

\section{Internationalization: firm-level perspective}

This section analyzes differences between international and domestic firms at the firm level. Summary statistics are reported in Table 4. The tests of medians indicate that international firms are larger, grow faster, have higher returns on assets, and carry on more international business than domestic firms do. The size difference between

\footnotetext{
${ }^{18}$ The interpretations for the Tobit regressions are valid in the case that the proportion of international firms in a country is different from zero, i.e. they form part of the uncensored part of the data.

19 To better assess the magnitude of the above results, note that the mean fraction of international firms in the sample is 13 percent, with a standard deviation of 16 percent.
} 
international and domestic firms is particularly large, almost a factor of six (275 million U.S. dollars versus 1,654 million). The middle panel provides the differences between medians and shows that all differences are statistically different from zero.

We can further analyze the differences in firm characteristics by providing Kernel distributions (Figure 4). The figure shows that, in terms of size, growth, returns on assets, and international business, the distribution of international firms is different than that of domestic firms. These differences are all statistically significant (according to the Kolmogorov-Smirnov test). From the charts and tests, the differences appear to be the greatest for the assets and foreign sales distributions, smaller for the sales growth distributions, with the differences the least for the return on assets' distribution. This complements the median comparisons in Table 4.

When separating developing and developed countries, differences between international and domestic firms remain similar. The only variation is that the differences among international and domestic firms from developing countries are less statistically significant than those for developed countries, but this may in part be a function of the number of firms.

The bottom panel in Table 4 provides tests of median differences between international firms from developed and developing countries and between domestic firms from both sets of countries. While the differences between international and domestic firms in developed countries tend to be similar to those in developing countries, international and domestic firms are different across developed and developing countries. International firms from developed countries tend to be larger and have a greater share of foreign sales than those from developing countries. But international firms from developing countries tend to have higher sales growth (although not statistically significant) and higher returns on assets than firms from developed countries do. These differences among international firms also carry through for domestic firms: domestic firms in developed countries are larger than domestic firms in developing countries are, while domestic firms in developing countries tend to grow faster (this time in a statistically significant way) and have higher returns. Furthermore, foreign sales are higher for domestic firms in developed countries than in developing countries. 
Table 4 thus suggests that international firms from developed countries do not differ from international firms from developing countries in a manner that varies from how domestic firms in developed countries differ from domestic firms in developing countries. For example, the average asset sizes of the international and domestic firms from developing countries are 916 and 165 million U.S. dollars, respectively; compared to 2,454 and 316 million U.S. dollars, respectively, for firms from developed countries. This means the average international firm is much larger than the average domestic firm, and the average international firm from a developed country is much larger than the average international firm from a developing country. Relatively though, the differences are similar: an international firm from a developing country is five to six times larger than a domestic firm versus seven to eight times large for an international firms from the developed countries. In other words, international firms appear to differ in similar ways from domestic firms in both sets of countries and there are no obvious differences in how firm characteristics explain internationalization for the two groups of countries.

We next investigate more formally the probability of internationalization using Probit and Cox estimates. The Probit regressions use firm information as of 1993 and thus try to predict whether firms are likely to go abroad over the following seven years. Consequently, it is quite a stringent test as it does not use any information on how firm characteristics may change over time and how that in turn may relate to internationalization, even when the firm only internationalizes towards the end of the seven years. It also does not use any potentially important information on the state of global financial markets and investor sentiment towards firms internationalizing, given that these are cross-sectional regressions with no time variation. The specifications employ both the firm characteristics that we have been discussing and use either country dummies or the usual country variables to control for any country characteristics affecting the probability of internationalization.

The results for the firm characteristics with country dummies (Table 5, upper panel) are consistent with the results from the median comparisons and uniformly so across the regression specifications. Larger firms and those firms growing faster are more likely to go abroad. This may imply that larger and better firms have both greater incentives and better chances to go abroad. More foreign sales also increase the chances 
of internationalization, supporting the idea that there is some collateral value to having international activities. The results for return on assets are less clear: although the coefficient is positive, it is not always statistically significant. Perhaps, other firm characteristics such as growth in sales already control for firm performance. Or return on assets is too noisy an indicator to explain internationalization choices.

Probit regressions for developed and developing countries separately find no major differences as all variables have the same sign and significance is generally maintained. The return on asset variable is not statistically significant for the sample of developed countries and only once for the sample of developing countries' firms, perhaps due to the noisy nature of this variable. While on balance the determinants of internationalization are very similar between the two groups of countries, there are some differences though in coefficient magnitudes. It appears in particular that firms from developing countries have greater sensitivity to firm characteristics, such as size, sales growth, and foreign sales.

Table 5, lower panel shows the regressions using time-varying country variables as controls. We find that all coefficients retain their sign (except for the return on assets) and statistical significance (with the exception of the foreign sales and growth variables, which give mixed results). Coefficients are also generally of the same order as those in the regression results with country dummies. This suggests that there are no specific time-varying country effects influencing significantly our results regarding the firm-level measures related to internationalization.

In terms of the economic significance of the coefficients, firm size appears to be particularly important, supporting other research and general perceptions. ${ }^{20}$ Quantitatively, for the case of an average firm and using the regressions with country dummies, a one percent increase in total assets would raise the probability of becoming international by approximately 1.4 percentage points. Similarly, a one percent increase in sales growth would raise the probability to become international by 0.8 percentage points. In the case of the remaining variables, the interpretation is slightly different as they are not in logarithms. Here, foreign sales shows large effects as a one standard deviation

\footnotetext{
${ }^{20}$ Recent work highlighting the importance of size in the internationalization decision includes Doidge et al. (2006) and Zingales (2006).
} 
increase raises the probability of becoming international by 0.4 percentage points. Return on assets is a quantitatively less important factor.

Reflecting the differences in magnitudes of coefficients, the economic significance of the coefficients is different for firms from developing versus developed countries. In the case of firm size, for instance, while for firms from developed countries the increase in the probability of internationalizing is similar to that for the whole sample (a one percent increase in size is related to a one percentage point increase in the probability of becoming international), for firms from developing countries a one percentage increase in size is much more important, with an increase of about four percentage points in the probability of becoming international. The same is observed for most other firm characteristics analyzed. In other words, own characteristics are much more important to become international for firms in developing countries compared to firms in developed countries. In other words, internationalization appears more sensitive to firm attributes among developing country firms.

The Cox regressions take a different approach than the Probit regressions as they use time-varying information on firm financial characteristics until the year before which the firm actually lists abroad. Relaxing this restriction can be important as firm characteristics can change over time. The results are reported in Table 6 where we again use both country dummies and country controls that may vary over time. In the Cox results, a coefficient greater than one indicates that increases in the variable enhance the probability of the firm going abroad and less than one decrease this probability. The coefficients directly indicate the percentage change in the probability of observing a firm becoming international, relative to the base probability, due to the change of one standard deviation in each explanatory variable.

The Cox results confirm the findings from the Probit regressions: firm size, sales growth, and foreign sales share are positively related to the probability of internationalizing. Performance measured by return on assets is positively related to the probability of going abroad, this time being statistically significant. The Cox regression results differentiated by country groups also confirm the general results. As in the regression results for all countries, most firm characteristics are statistically significant and equally so for developed and developing countries. Sales growth is an exception, as 
this variable is not statistically significant for developing countries; and return on assets is not statistically significant in all cases. For the Cox estimation, there are little differences in coefficient magnitudes between developing and developed countries. Most firm characteristics appear equally important for the probability of going abroad, except for the foreign sales variable which is more important for developing countries. And there are again very few differences in terms of coefficients' sign and statistical significance between the regression results that use country dummies and time-varying country controls (upper and lower panels). The exceptions are that with country control variables sales growth is significant in one specification and that return on assets is significant for developing countries in both specifications, and the coefficient on the foreign sales variable is larger for developed countries than for developing countries.

To interpret and compare the economic magnitude of the effects of individual firm characteristics on the hazard ratio, the logarithm of the estimated coefficients is to be multiplied by one standard deviation of the explanatory variables. Again, firm's size yields the largest impact on the decision to internationalize. The standard deviation of the logarithm of total assets (1.61) is multiplied by the logarithm of the coefficient (1.716); the exponential of the obtained number results in the percentage change in the probability becoming international. This exercise yields a 140 percent increase in the baseline probability of becoming international with a one standard deviation increase in size for an average firm. As was the case for the Probit model, foreign sales also seem economically important, followed by sales growth. The economic effect of return on assets seems relatively small. $^{21}$

One other way to analyze the importance of firm attributes in terms of accessing international equity markets is to compare the characteristics of the international firms before and after internationalization, relative to the control group. This can provide a confirmation of the characteristics and desires of firms to go abroad. We do this by regressing, for the whole sample period and using all firms, the four firm characteristics we have studied so far as dependent variables on before and after internationalization firm-specific dummies. The before internationalization dummy equals one for all the years before the year a firm becomes international, and zero otherwise. The after

\footnotetext{
${ }^{21}$ These magnitudes are quite similar to those found by Pagano et al. (2002).
} 
internationalization dummy equals one in and after the year when a firm becomes international, and zero otherwise. The regressions also include country, industry, and year dummies. The coefficients for the before and after dummies thus tell whether international firms are statistically different from domestic firms, both before and after their internationalization. Tests of equality of the before and after coefficients tell whether firm attributes change with internationalization.

Table 7 provides the 8 coefficients for the four regressions. The results show that the average firm before it becomes international is larger, has higher sales growth, has a higher return on assets, and has more foreign sales to assets than domestic firms do, after controlling for country, industry, and time effects. All these differences are statistically significant. The results also show that subsequent to internationalization, and relative again to domestic firms, the average international firm is larger in size, grows at a faster pace, and has a higher share of foreign sales. The coefficient for the return on assets regression is not statistically significant, but all other coefficients are. Comparing the coefficients of the after internationalization dummies with those of the before internationalization dummies, reported at the bottom of Table 7 , we find all to be statistically different, but signs differ. Upon becoming international, an international firm becomes even larger in size and has an even higher share of foreign sales, but continues to grow at a somewhat slower pace and lowers its return on assets. The before and after internationalization effects thus confirm the Probit and Cox regression results. Upon internationalization, firms grow more, perhaps due to better access to financing. The increase in the share of foreign sales suggests that financial internationalization is part of a larger trend of firms' international integration.

\section{Conclusions}

This paper has shown that, by analyzing the use by firms of international equity markets, the extent of international financial integration appears more limited than commonly thought. Although many countries have few firms participating in international markets, much fewer countries have a non-negligible proportion of internationally active firms. Moreover, only certain firms and countries participate in international equity markets. Both macroeconomic and microeconomic factors relate to 
the participation of firms abroad and can explain the lack of widespread international financial integration. With respect to country characteristics, we find that more developed countries with better macroeconomic (but worse institutional) conditions and more open economies have more international firms. Regarding microeconomic aspects, we find that larger firms and firms with more foreign sales are significantly more likely to internationalize. Firms that grow faster and have higher rates of returns are also more prone to going abroad.

This paper could be expanded in many directions, which may enlighten several academic and policy debates. First, more tests could be performed to extend the results. For example, we did not distinguish between the firms that only list or trade in international markets and those that raise capital in those markets, nor between the forms of listing (cross-listing versus ADRs/GDRs). Theory suggests that similar, but not identical factors affect these types of choices. Also, we have not used any firm-specific governance variables, such as ownership structures, which, although difficult to collect, may be important in the listing abroad decision. Clearly, firms can try to bind themselves to higher corporate governance standards through other means, such as having (more) independent directors, hiring better accountants, and so forth. Whether these voluntary mechanisms alone are effective in less developed countries and whether internationalization serves as a complement or substitute corporate governance tool is an important research and policy issue.

A second area of possible extensions is related to the finding that only few countries and certain firms participate in international markets and stand to gain potentially from the direct benefits of internationalization. More research can help understand whether firms that do not have a direct link to the international financial system obtain positive or negative spillovers and what the associated welfare effects may be. Positive spillovers might occur if the benefits reaped by international firms get transmitted to domestic firms, for example, through freeing up domestic financing for domestic firms or creating more integrated financial markets. Negative spillovers can be present when internationalization adversely affects domestic market development, especially market liquidity. ${ }^{22}$

\footnotetext{
${ }^{22}$ See Levine and Schmukler (2006a, b) and references therein.
} 
Third, understanding better the extent to which country and firm characteristics allow firms to issue capital internationally may help design policies that increase the likelihood of firms to access global capital markets and in such a way as to reap the associated gains of lower costs and better terms. For example, it may be that firms from weaker countries can use international markets to bind themselves to higher standards of investor protection only when the country of origin has passed some hurdle in terms macroeconomic development. More broadly, the desire of firms to internationalize might only be met after country characteristics allow them to do so. And, for international financial centers, a better understanding of the drivers of internationalization will help guide their policies, including listing requirements and other regulations. In fact, recent work suggests that the benefits of listing in the U.S. have diminished in recent years (after our sample ends), adversely affecting the business of international stock exchanges. $^{23}$

Fourth, the paper sheds some light on the prospects and viability of stock exchanges in countries of different characteristics. It seems that countries that are sufficiently far along in developing the macroeconomic and institutional foundations of their financial markets, risk the prospects of triggering migration from their stock exchanges as better foundation mean that firms can access international markets. This has implications for local market capitalization, liquidity, and general development, with the specifics depending on among others the country's corporate sector structure. It can also imply that (further) investments in the development of a local trading system or stock exchange are not necessarily warranted as local markets are not viable and efficient on their own.

Fifth, the paper provides insights into which firms cannot be expected to access international equity markets, even when certain policies improve, and are therefore left to issue capital, trade, and list domestically. For example, small firms with little activity will have difficulty accessing international markets. Tailoring the forms of local capital market development to these firms specifically would be important. The preferred solution may well differ from that of a fully-fledged stock exchange as it exists in

\footnotetext{
${ }^{23}$ In this context, there has been debate in the U.S. on the impact of the 2002 Sarbanes-Oxley Act on reducing foreign listings. See, for example, Zingales (2006).
} 
advanced countries. ${ }^{24}$ More generally, to design the preferred form of financial market development will hinge importantly on understanding the nature and determinants of international financial integration.

${ }^{24}$ See de la Torre and Schmukler (2006) for a detailed discussion. 


\section{References}

Baker, H. K., Nofsinger, J., Weaver, D., 1999. International Cross-Listing and Visibility. NYSE Working Paper 99-01, January.

Baldwin, R., Martin, P., 1999. Two Waves of Globalization: Superficial Similarities, Fundamental Differences. In: Siebert, H. (Ed.), Globalisation and Labour. J.C.B. Mohr for Kiel Institute of World Economics, Tubingen, 1999.

Bekaert, G., Campbell, H., Lundblad, C., 2005. Does Financial Liberalization Spur Economic Growth? Journal of Financial Economics 77 (1), 3-55.

Bekaert, G., Campbell, H., Lundblad, C., Siegel, S., 2006. Global Growth Opportunities and Market Integration. EFA 2004 Maastricht Meetings Paper No. 1697.

Benos, E., Weisbach, M., 2004. Private Benefits and Cross-Listings in the United States. Emerging Markets Review 5 (2), 217-240.

Bordo, M., Eichengreen, B., Irwin, D., 1999. Is Globalization Today Really Different than Globalization a Hundred Years Ago? NBER Working Paper 7195. Revised version published in: Brookings Trade Policy Forum 1999, 1-50.

Caballero, R., Krishnamurthy, A., 2001. International and Domestic Collateral Constraints in a Model of Emerging Market Crises. Journal of Monetary Economics 48 (3), 513-548.

Caballero, R., Krishnamurthy, A., 2002. A Dual Liquidity Model for Emerging Markets. American Economic Review 92 (2), 33-37.

Cantale, S., 1996. The Choice of a Foreign Market as a Signal. INSEAD Working Paper.

Chaplinsky, S., Ramchand, L., 2000. The Impact of Global Equity Offerings. Journal of Finance 55 (6), 2767-2790.

Claessens, S., Klingebiel, D., Schmukler, S., 2006. Stock Market Development and Internationalization: Do Economic Fundamentals Spur Both Similarly? Journal of Empirical Finance 13 (3), 316-350.

Coffee, J., 1999. The Future as History: The Prospects for Global Convergence in Corporate Governance and its Implications. Northwestern Law Review 93, 641708.

de la Torre, A., Gozzi, J. C., Schmukler, S., 2006. Stock Market Development under Globalization: Whither the Gains from Reforms? Journal of Banking and Finance, forthcoming.

de la Torre, A., Schmukler, S., 2006. Emerging Capital Markets and Globalization: The Latin American Experience. Stanford University Press.

Doidge, C., Karolyi, G., Lins, K., Miller, D., Stulz, R., 2006. Private Benefits of Control, Ownership, and the Cross-Listing Decision. NBER Working Paper 11162.

Doidge, C, Karolyi, G., Stulz, R., 2004. Why Are Foreign Firms Listed in the U.S. Worth More? Journal of Financial Economics 71 (2), 205-238.

Foerster, S., Karolyi, G., 1998. Multimarket Trading and Liquidity: A Transaction Data Analysis of Canada-U.S. Interlistings. Journal of International Financial Markets, Institutions and Money 8 (3-4), 393-412.

Foucault, T., Gehrig, T., 2006. Stock Price Informativeness, Cross-Listings and Investment Decisions. EFA 2006 Zurich Meetings.

Fuerst, O., 1998. A Theoretical Analysis of the Investor Protection Regulations Argument for Global Listing of Stocks. Mimeo, Yale School of Management. 
Gozzi, J. C., Levine, R., Schmukler, S., 2006. Internationalization and the Evolution of Corporate Valuation. World Bank Policy Research Working Paper Series 3933. Previously released as NBER Working Paper 11023, 2005. Journal of Financial Economics, forthcoming.

Grammig, J., Melvin, M., Schlag, C., 2005. The Role of U.S. Trading in Pricing Internationally Cross-Listed Stocks. EFA 2004 Maastricht Meetings Paper No. 3267.

Hale, G., 2006. Bonds or Loans? The Effect of Macroeconomic Fundamentals. Cowles Foundation Discussion Paper No. 1403. The Economic Journal, forthcoming.

Hale, G., Santos, J., 2005. The Decision to First Enter the Public Bond Market: The Role of Firm Reputation, Funding Choices, and Bank Relationships. Yale ICF Working Paper No. 04-47.

Kadlec, G., McConnell, J., 1994. The Effect of Market Segmentation and Illiquidity on Asset Prices: Evidence from Exchange Listings. Journal of Finance 49 (2), 611636.

Kaminsky, G., Schmukler, S., 2003. Short-Run Pain, Long-run Gain: The Effects of Financial Liberalization. NBER Working Paper 9787.

Kose, M. A., Prasad, E., Rogoff, K., Wei, S., 2006. Financial Globalization: A Reappraisal. NBER Working Papers 12484.

Levine, R., 2005. Finance and Growth: Theory and Evidence. In: Aghion, P., Durlauf, S. (Eds.), Handbook of Economic Growth. Elsevier Science.

Levine, R., Schmukler, S., 2006a. Internationalization and Stock Market Liquidity. Review of Finance 10 (1), 153-187.

Levine, R., Schmukler, S., 2006b. Migration, Spillovers, and Trade Diversion: The Impact of Internationalization on Domestic Stock Market Activity. Journal of Banking and Finance, forthcoming.

Levy Yeyati, E., Schmukler, S., Van Horen, N., 2006. International Financial Integration through the Law of One Price. World Bank Working Paper 3897.

Licht, A., 2003. Cross-Listing and Corporate Governance: Bonding or Avoiding? Chicago Journal of International Law 4 (1), 141-163.

Lins, K., Strickland, D., Zenner, M., 2005. Do Non-U.S. Firms Issue Equity on U.S. Stock Exchanges to Relax Capital Constraints? Journal of Financial and Quantitative Analysis 40 (1), 109-133.

Lothian, J., 2002. The Internationalization of Money and Finance and the Globalization of Financial Markets. Journal of International Money and Finance 21, 699-724.

Miller, D., Puthenpurackal, J., 2002. The Costs, Wealth Effects and Determinants of International Capital Raising: Evidence from Public Yankee Bonds. Journal of Financial Intermediation 11 (4), 455-485.

Noronha, G., Sarin, A., Saudagaran, S., 1996. Testing for Microstructure Effects of International Dual Listings Using Intraday Data. Journal of Banking and Finance 20 (6), 965-983.

Obstfeld, M., Taylor, A., 2002. Globalization and Capital Markets. In: Bordo, M., Taylor, A., Williamson, J. (eds.), Globalization and Capital Markets. University of Chicago Press.

Obstfeld, M., Taylor, A., 2004. Global Capital Markets: Integration, Crises, and Growth. Cambridge University Press. 
Pagano, M., Panetta, F., Zingales, L., 1998. Why Do Companies Go Public? An Empirical Analysis. Journal of Finance 53 (1), 27-64.

Pagano, M., Röell, A., Zechner, J., 2002. The Geography of Equity Listing: Why Do Companies List Abroad? Journal of Finance 57 (6), 2651-2694.

Rajan, R., Zingales, L., 2003. The Great Reversals: The Politics of Financial Development in the Twentieth Century. Journal of Financial Economics 69 (1), 5 50 .

Reese, W., Weisbach, M., 2002. Protection of Minority Shareholder Interests, CrossListing in the United States, and Subsequent Equity Offerings. Journal of Financial Economics 66 (1), 65-104.

Sarkissian, S., Schill, M., 2004. The Overseas Listing Decision: New Evidence of Proximity Preference. Review of Financial Studies 17 (3), 769-809.

Saudagaran, S., 1988. An Empirical Study of Selected Factors Influencing the Decision to List on Foreign Stock Exchanges. Journal of International Business Studies 19 (1), 101-127.

Schmukler, S., Vesperoni, E., 2006. Financial Globalization and Debt Maturity in Emerging Economies. Journal of Development Economics, 79 (1), 183-207.

Siegel, J., 2005. Can Foreign Firms Bond Themselves Effectively by Renting U.S. Securities Laws? Journal of Financial Economics 75 (2), 319-359.

Smith, K., Sofianos, G., 1997. The Impact of an NYSE Listing on the Global Trading of Non-U.S. Stocks. NYSE Working Paper 97-02.

Vinhas de Souza, L., 2005. Financial Liberalization and Business Cycles: The Experience of the New EU Member States. In: Batten, J., Kearney, C. (Eds.), Emerging European Financial Markets: Independence and Integration Post-enlargement. Elsevier, Netherlands.

Zingales, L., 2006. Is The U.S. Capital Market Losing Its Competitive Edge? Journal of Economic Perspectives, forthcoming. 
Figure 1

Internationalization Process

This figure shows three indicators of the internationalization process in 106 developed and developing countries between 1989 and 2000. The top panel shows the number of firms that became international each year. The middle panel shows the evolution of the share of market capitalization of international firms to total market capitalization. The bottom panel shows the evolution of the share of value traded abroad to value traded domestically. The United States and the United Kingdom are not included in the sample due to the classification of these countries as international financial centers. International firms are those identified as having at least one active depositary receipt program, having raised equity capital in international markets, or being listed on the London Stock Exchange, NASDAQ, or NYSE. Countries are divided by income level following the classification of the World Development Indicators, World Bank at the beginning of the sample period (1989).

Number of New International Firms

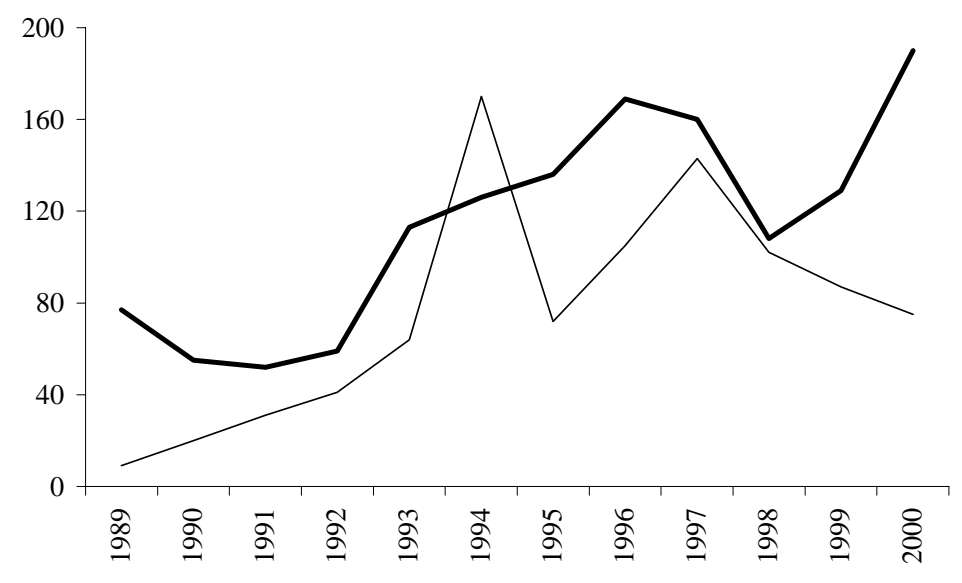

Market Capitalization of International Firms/Total Market Capitalization

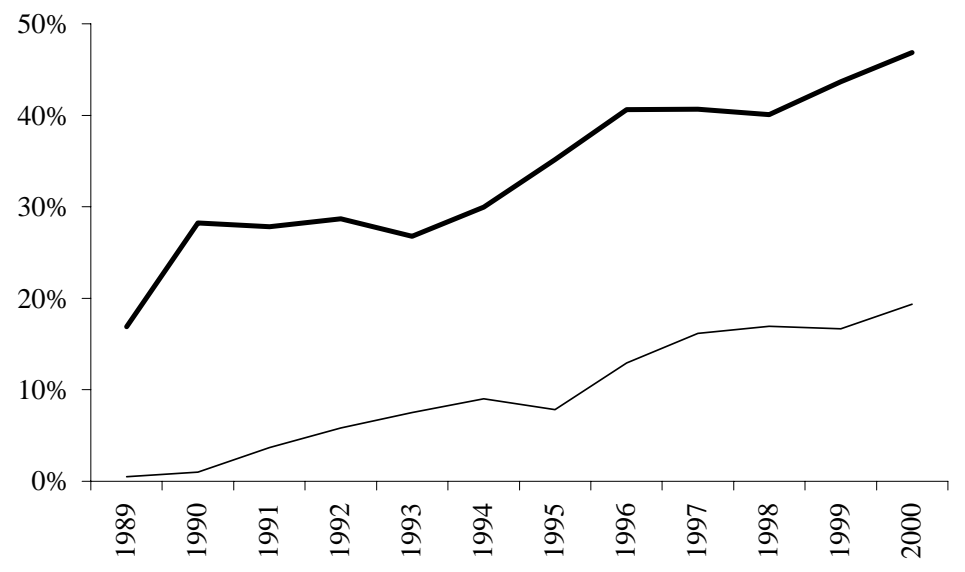

Value Traded Abroad/Value Traded Domestically

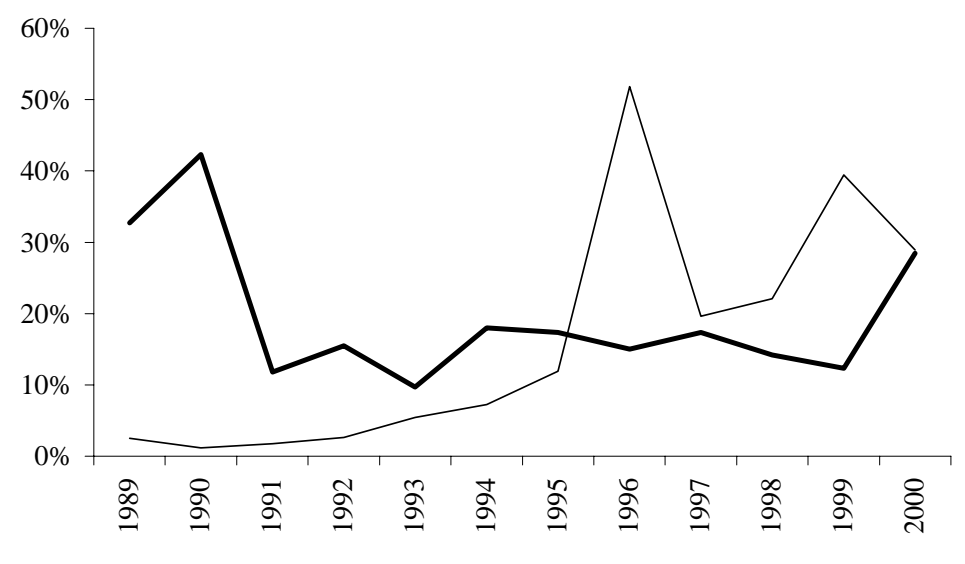

- Developed Countries — Developing Countries 
Figure 2

\section{Internationalization Process}

This figure shows the degree of internationalization at the country and firm level between 1989 and 2000. The top panel shows the fraction of countries with international activity, measured by having at least one international firm or by having at least ten percent of international firms. The bottom panel shows the fraction of international firms to total firms in two ways: (i) the worldwide total number of international firms to the total number of firms each year and (ii) the cross-country average of each country's proportion of international firms to total firms. The United States and the United Kingdom are not included in the sample due to the classification of these countries as international financial centers. International firms are those identified as having at least one active depositary receipt program, having raised equity capital in international markets, or being listed on the London Stock Exchange, NASDAQ, or NYSE.

\section{Proportion of Countries with International Firms}

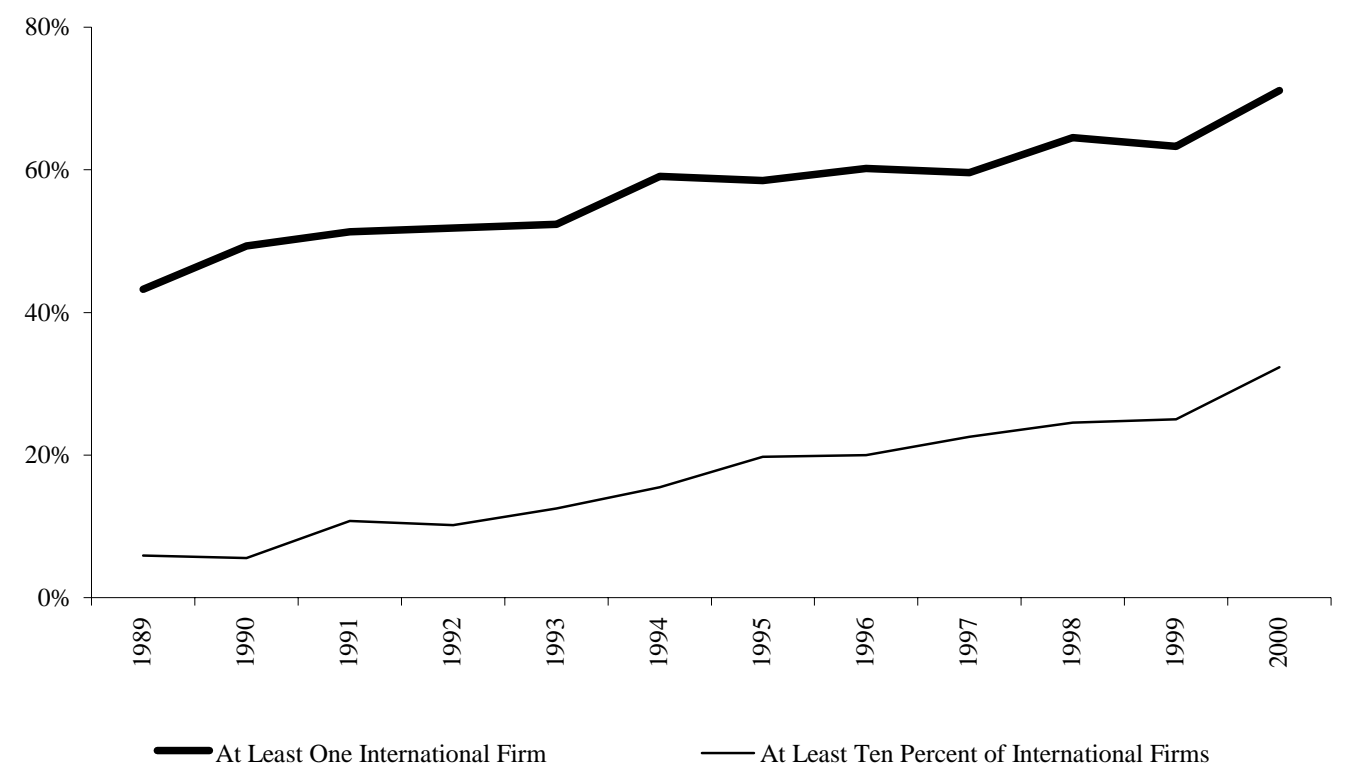

\section{Proportion of International Firms Relative to Total Firms}

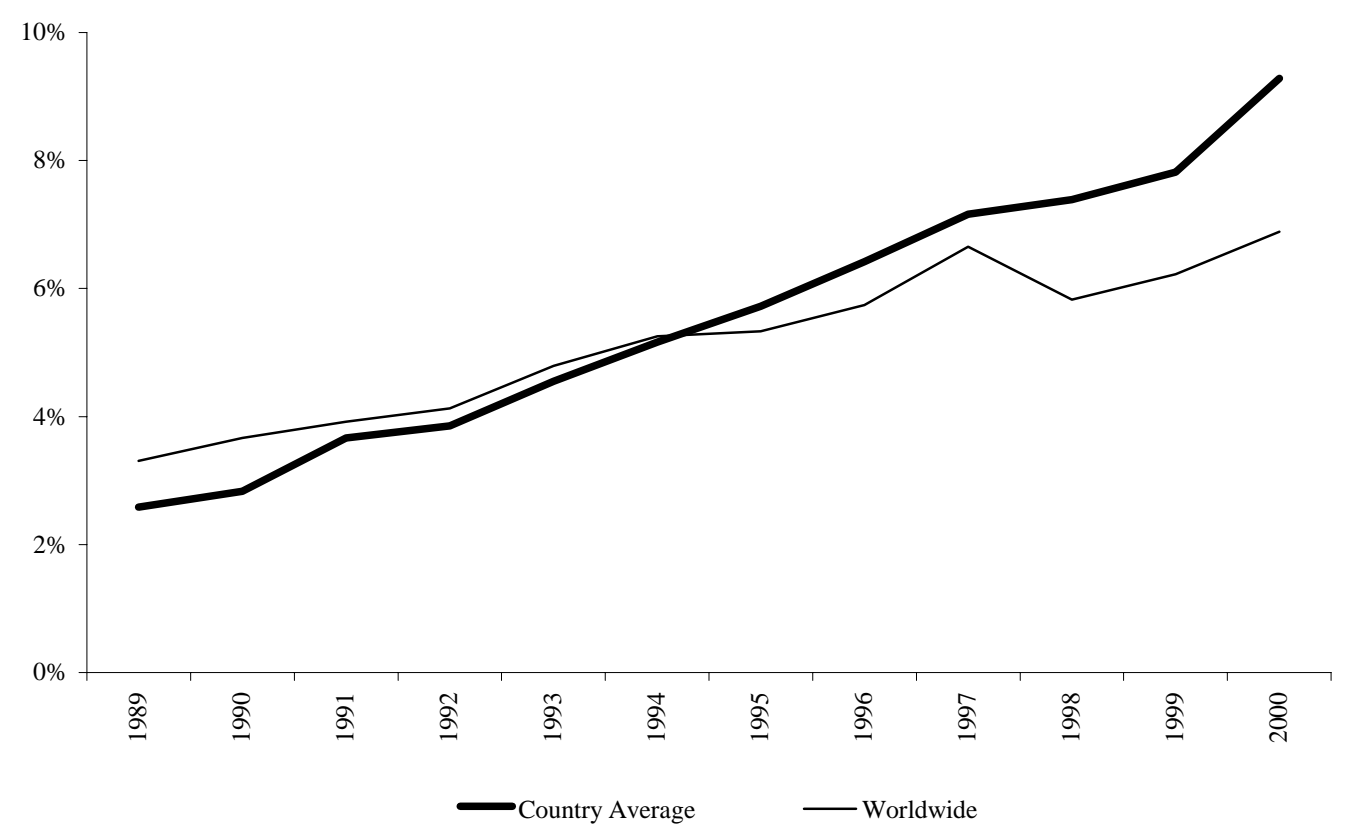


Figure 3

Distribution of Countries According to International Activity

This figure shows countries (bars) sorted by the extent of internationalization (measured in three different ways) in 2000. Countries are divided into five equally-sized groups (quintiles); the average values for each quintile are also reported. The sample only includes countries with data available on domestic stock market activity during 2000. International firms are those identified as having at least one active depositary receipt program, having raised equity capital in international markets, or being listed on the London Stock Exchange, NASDAQ, or NYSE. The United States and the United Kingdom are not included in the sample due to their classification as international financial centers.

Number of International Firms/Number of Firms Listed in the Domestic Market

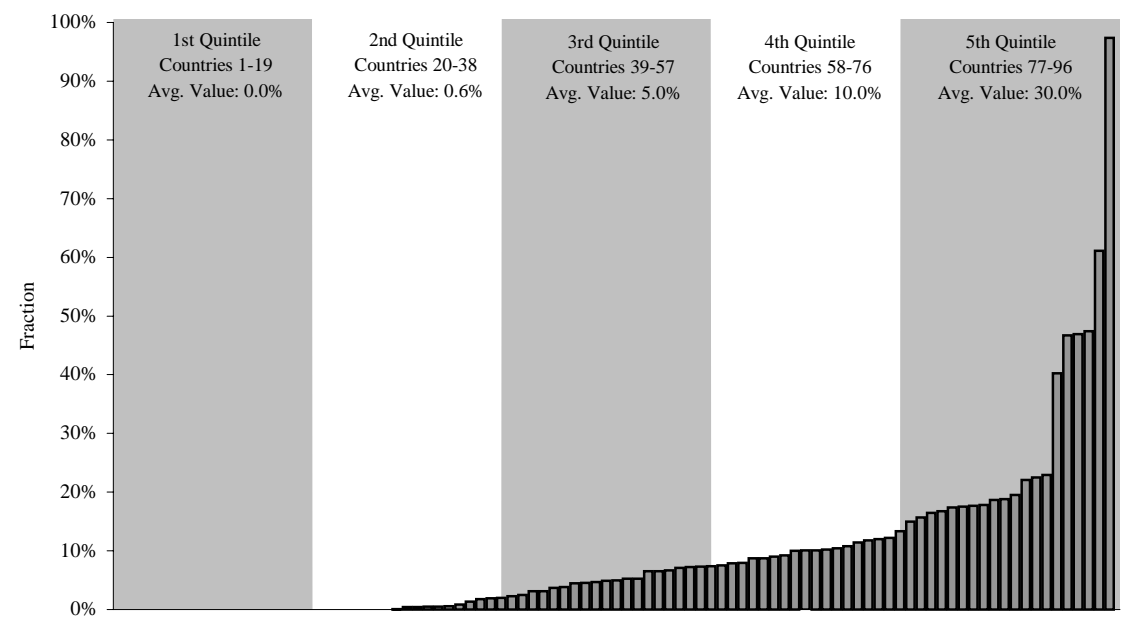

Market Capitalization of International Firms/Total Market Capitalization

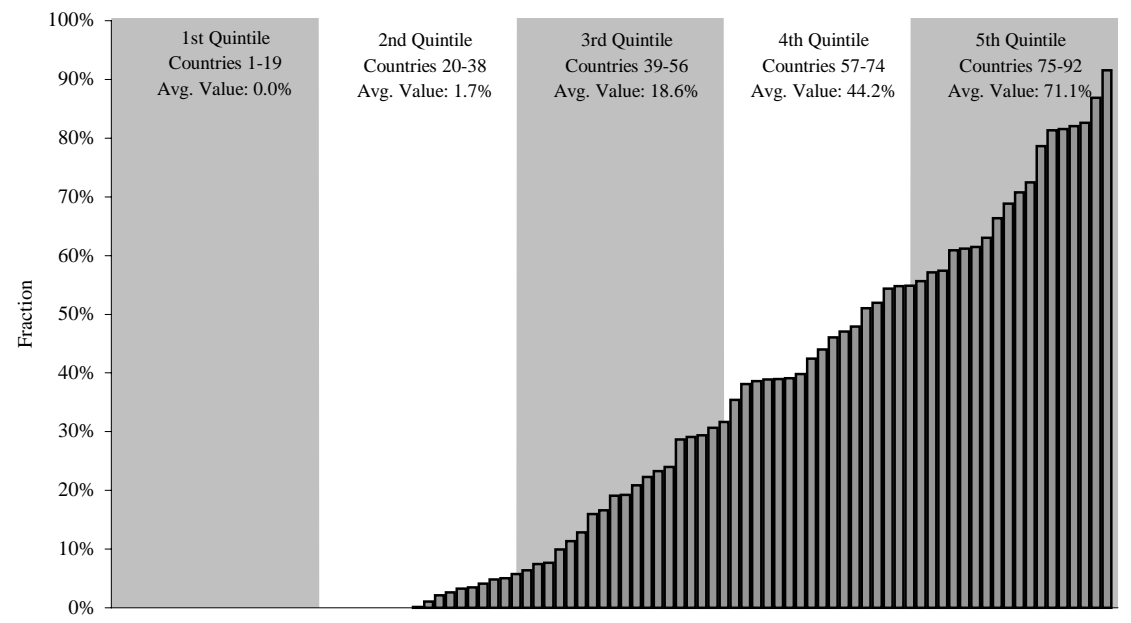

Value Traded Abroad/Value Traded Domestically

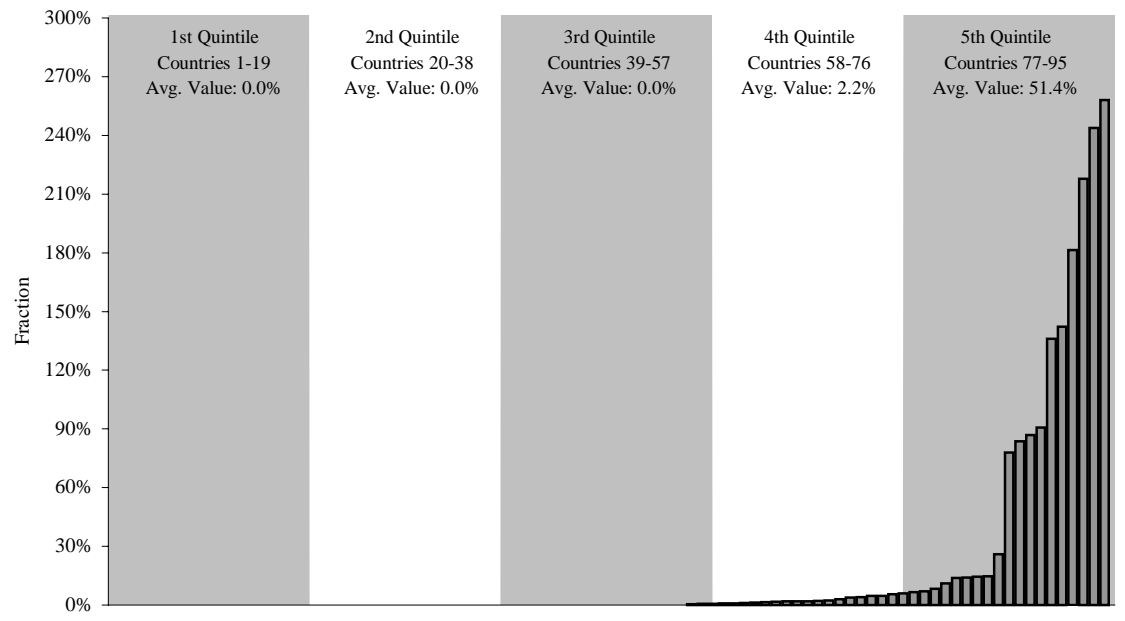




\section{Figure 4}

\section{Distribution of Firm Characteristics for Domestic and International Firms}

This figure shows the estimated Kernel distributions for total assets, sales growth, return on assets, and foreign sales to total sales for domestic and international firms. The Kolmogorov-Smirnov test for the equality of distributions and associated statistic (D) and p-value are reported in each case. The null hypothesis of the test is that the distribution of firm characteristics is equal across domestic and international firms. International firms are those identified as having at least one active depositary receipt program, having raised equity capital in international markets, or being listed on the London Stock Exchange, NASDAQ, or NYSE. The United States and the United Kingdom are not included in the sample due to their classification as international financial centers.
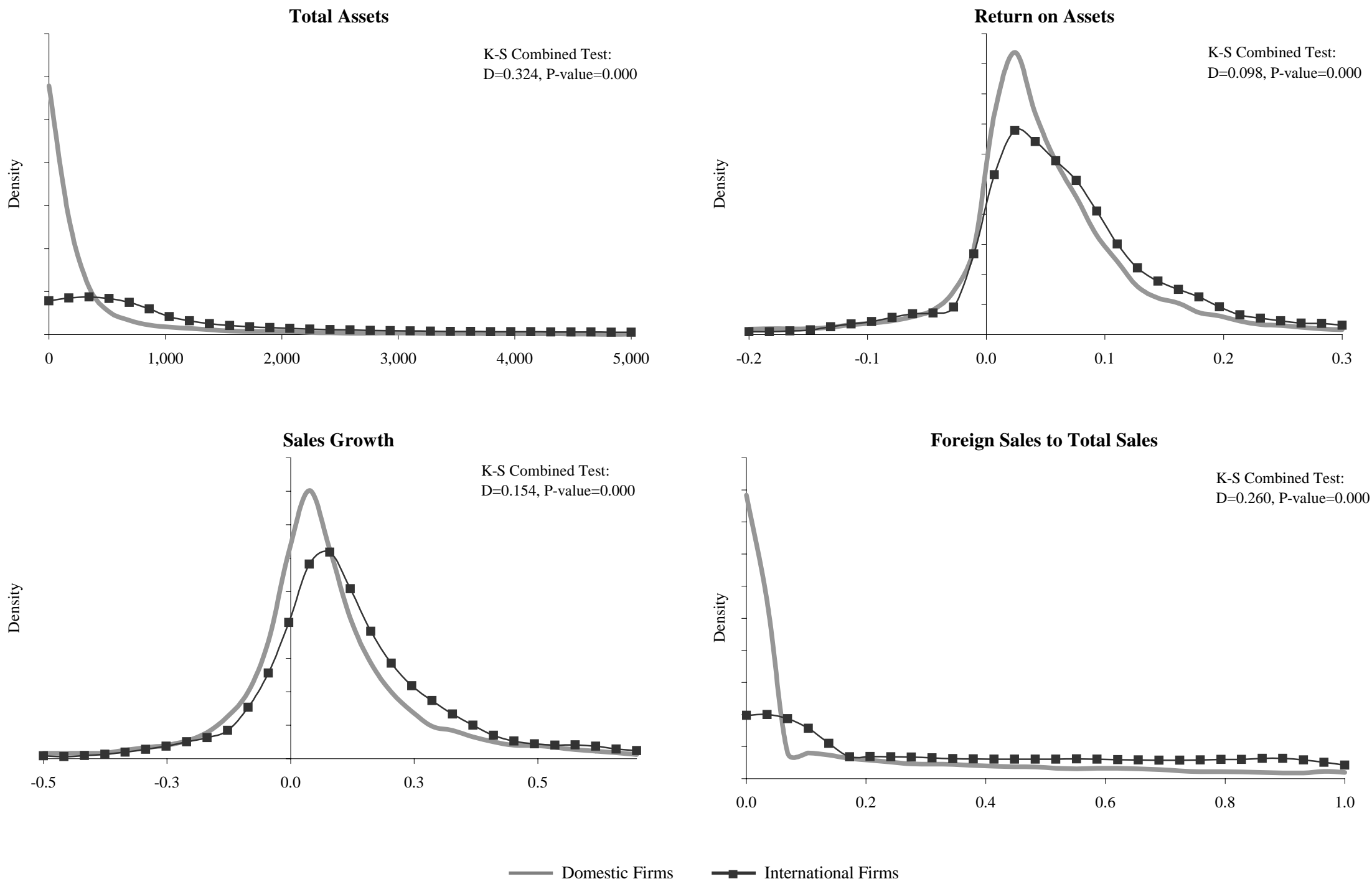
Table 1

Stock Market Internationalization by Region

This table presents data on the extent of internationalization at the country level by region in 2000. The sample only includes countries with active domestic stock markets at any time during the sample period (1989-2000). Countries are classified as having activity in international equity markets if at least one firm from the country is classified as international or if the country shows trading activity or capital raising activity at any point during the sample period. International firms are those identified as having at least one active depositary receipt program, having raised equity capital in international markets, or being listed on the London Stock Exchange, NASDAQ, or NYSE. The United States and the United Kingdom are not included in the sample due to their classification as international financial centers. Data for market capitalization of international firms and value traded abroad are averages across countries in each region. Countries are divided by income level following the classification of the World Development Indicators, World Bank at the beginning of the sample period (1989).

\begin{tabular}{|c|c|c|c|c|c|c|c|}
\hline Region & $\begin{array}{c}\text { Number of } \\
\text { Countries }\end{array}$ & $\begin{array}{c}\text { Number of } \\
\text { Countries with } \\
\text { Active Stock } \\
\text { Markets } \\
\end{array}$ & $\begin{array}{c}\text { Number of } \\
\text { Countries with } \\
\text { International } \\
\text { Activity } \\
\end{array}$ & $\begin{array}{c}\text { Share of } \\
\text { Countries with } \\
\text { International } \\
\text { Activity } \\
\end{array}$ & $\begin{array}{c}\text { Number of } \\
\text { Firms Listed in } \\
\text { the Domestic } \\
\text { Market } \\
\end{array}$ & $\begin{array}{c}\begin{array}{c}\text { Number of } \\
\text { International } \\
\text { Firms }\end{array} \\
\end{array}$ & 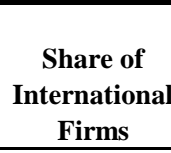 \\
\hline Developing Countries & 161 & 82 & 48 & $\mathbf{5 8 . 5 \%}$ & 23,910 & 889 & $3.7 \%$ \\
\hline Africa (Developing) & 53 & 17 & 11 & $64.7 \%$ & 2,278 & 98 & $4.3 \%$ \\
\hline Asia (Developing) & 34 & 21 & 10 & $47.6 \%$ & 11,504 & 332 & $2.9 \%$ \\
\hline Eastern Europe (Including Former Soviet Union) & 27 & 21 & 14 & $66.7 \%$ & 7,632 & 151 & $2.0 \%$ \\
\hline Latin America \& Caribbean & 34 & 20 & 10 & $50.0 \%$ & 1,743 & 258 & $14.8 \%$ \\
\hline Developed Countries & 44 & 29 & 22 & $75.9 \%$ & 13,061 & 1,657 & $12.7 \%$ \\
\hline Total & 205 & 111 & 70 & $63.1 \%$ & 36,971 & 2,546 & $6.9 \%$ \\
\hline
\end{tabular}

\begin{tabular}{|c|c|c|c|c|c|c|}
\hline Region & $\begin{array}{c}\text { Total Market } \\
\text { Capitalization/ } \\
\text { GDP } \\
\end{array}$ & $\begin{array}{c}\text { Market } \\
\text { Capitalization } \\
\text { of International } \\
\text { Firms/GDP } \\
\end{array}$ & $\begin{array}{c}\text { Market } \\
\text { Capitalization } \\
\text { of International } \\
\text { Firms/Total } \\
\text { Market } \\
\text { Capitalization } \\
\end{array}$ & $\begin{array}{c}\text { Value Traded } \\
\text { Domestically/ } \\
\text { GDP } \\
\end{array}$ & $\begin{array}{l}\text { Value Traded } \\
\text { Abroad/GDP }\end{array}$ & $\begin{array}{c}\text { Value Traded } \\
\text { Abroad/Value } \\
\text { Traded } \\
\text { Domestically } \\
\end{array}$ \\
\hline Developing Countries & $27.4 \%$ & $5.3 \%$ & $19.9 \%$ & $14.4 \%$ & $0.8 \%$ & $13.5 \%$ \\
\hline Asia (Developing) & $35.6 \%$ & $5.1 \%$ & $15.2 \%$ & $31.6 \%$ & $0.6 \%$ & $1.7 \%$ \\
\hline Eastern Europe (Including Former Soviet Union) & $11.3 \%$ & $4.3 \%$ & $28.9 \%$ & $4.2 \%$ & $0.1 \%$ & $1.1 \%$ \\
\hline Latin America \& Caribbean & $29.0 \%$ & $4.7 \%$ & $23.6 \%$ & $3.1 \%$ & $2.0 \%$ & $61.2 \%$ \\
\hline Developed Countries & $109.1 \%$ & $61.8 \%$ & $46.9 \%$ & $86.1 \%$ & $12.8 \%$ & $28.5 \%$ \\
\hline
\end{tabular}


Table 2.a

\section{Stock Market Internationalization and Country Characteristics}

This table reports the medians and the Mann-Whitney U-test of equality of medians for different characteristics of countries classified according to their level of internationalization over the sample period (1989-2000). The top panel includes the whole sample of countries with activity in international equity markets. Countries are classified as having activity in international equity markets if at least one firm from the country is classified as international or if the country shows trading activity or capital raising activity at any point during the sample period. International firms are those identified as having at least one active depositary receipt program, having raised equity capital in international markets, or being listed on the London Stock Exchange, NASDAQ, or NYSE. In the bottom panel, countries with activity in international equity markets are divided according to the average market capitalization of international firms over the total stock market capitalization using data for the whole period. The sample only includes countries with active domestic stock markets at any time during the sample period. The United States and the United Kingdom are not included in the sample due to their classification as international financial centers.

All Countries

\begin{tabular}{|c|c|c|c|c|c|c|}
\hline & \multicolumn{2}{|c|}{$\begin{array}{l}\text { Median } \\
\end{array}$} & \multicolumn{2}{|c|}{ Number of Observations } & \multicolumn{2}{|c|}{ Mann-Whitney U-Test } \\
\hline & $\begin{array}{c}\text { Countries without } \\
\text { Activity in } \\
\text { International } \\
\text { Equity Markets } \\
\end{array}$ & $\begin{array}{c}\text { Countries with } \\
\text { Activity in } \\
\text { International } \\
\text { Equity Markets }\end{array}$ & $\begin{array}{c}\text { Countries without } \\
\text { Activity in } \\
\text { International } \\
\text { Equity Markets }\end{array}$ & $\begin{array}{c}\text { Countries with } \\
\text { Activity in } \\
\text { International } \\
\text { Equity Markets }\end{array}$ & Z-statistic & P-value \\
\hline Size & & & & & & \\
\hline Log of GDP (Million U.S. dollars) & 8.73 & 11.20 & 456 & 835 & -21.70 & 0.00 \\
\hline Income Level & & & & & & \\
\hline Log of GDP per capita (U.S. dollars) & 7.32 & 8.19 & 452 & 835 & -10.69 & 0.00 \\
\hline Macroeconomic Policies & & & & & & \\
\hline Log of $(1+$ Inflation $)$ & 0.08 & 0.06 & 376 & 797 & 0.41 & 0.68 \\
\hline Fiscal Surplus/GDP & 0.03 & 0.02 & 316 & 710 & 2.47 & 0.01 \\
\hline Openess & & & & & & \\
\hline Stock Market Liberalization & 0.00 & 1.00 & 240 & 696 & -17.15 & 0.00 \\
\hline Trade (Exports+Imports)/GDP & 0.80 & 0.67 & 254 & 802 & 5.13 & 0.00 \\
\hline Institutional Framework & & & & & & \\
\hline Law and Order & 4.00 & 4.00 & 30 & 69 & -1.26 & 0.21 \\
\hline Investor Protection & 4.70 & 5.30 & 31 & 67 & -1.84 & 0.07 \\
\hline
\end{tabular}

Countries with Activity in International Equity Markets - by Market Capitalization

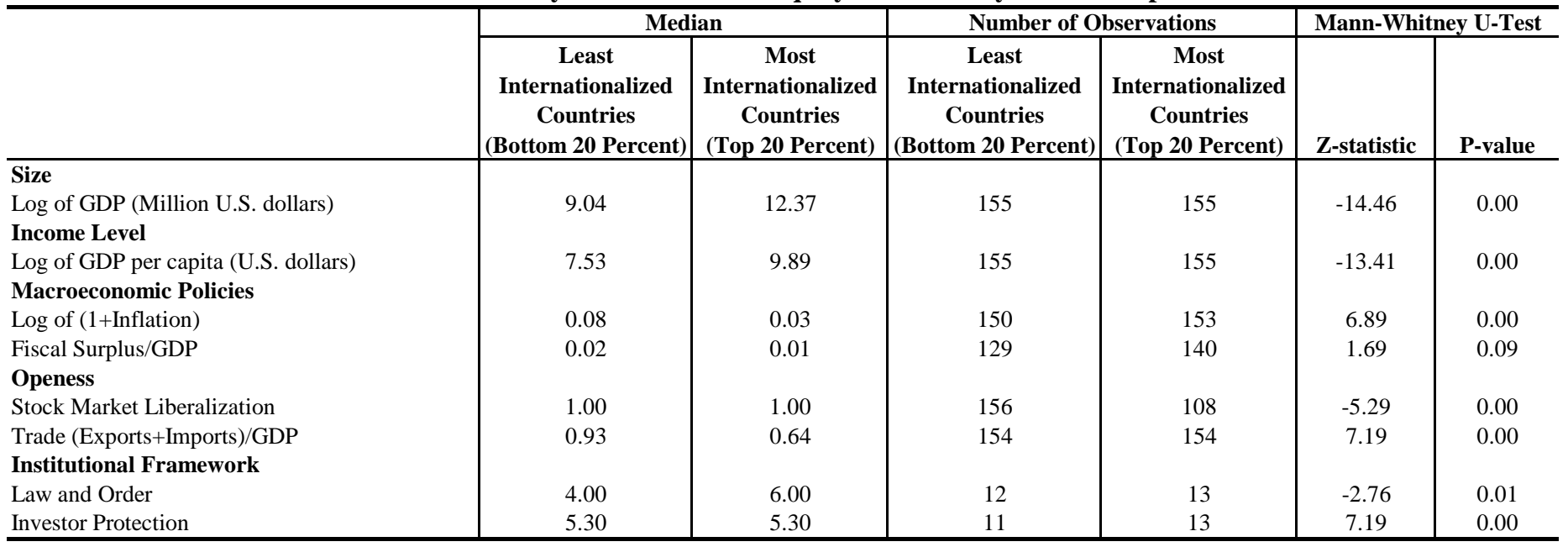


Table 2.b

Stock Market Internationalization and Country Characteristics

This table reports the medians and the Mann-Whitney U-test of equality of medians for different characteristics of countries classified according to their level of internationalization, over the sample period (1989-2000). Countries are classified as having activity in international equity markets if at least one firm from the country is classified as international at any point during the sample period. International firms are those identified as having at least one active depositary receipt program, having raised equity capital in international markets, or being listed on the London Stock Exchange, NASDAQ, or NYSE. In the top panel, countries with activity in international equity markets are divided according to the average value traded abroad over the value traded domestically using data for the whole period. In the bottom panel, countries with activity in international equity markets are divided according to the average number of international firms over the total number of firms using data for the whole period. The sample only includes countries with active domestic stock markets at any time during the sample period. The United States and the United Kingdom are not included in the sample due to their classification as international financial centers.

Countries with Activity in International Equity Markets - by Value Traded

\begin{tabular}{|c|c|c|c|c|c|c|}
\hline \multirow[b]{2}{*}{ Firm-Level Variables } & \multicolumn{2}{|c|}{ Median } & \multicolumn{2}{|c|}{ Number of Observations } & \multicolumn{2}{|c|}{ Mann-Whitney U-Test } \\
\hline & $\begin{array}{c}\text { Least } \\
\text { Internationalized } \\
\text { Countries } \\
\text { (Bottom 20 Percent) }\end{array}$ & $\begin{array}{c}\text { Most } \\
\text { Internationalized } \\
\text { Countries } \\
\text { (Top 20 Percent) }\end{array}$ & $\begin{array}{c}\text { Least } \\
\text { Internationalized } \\
\text { Countries } \\
\text { (Bottom } 20 \text { Percent) }\end{array}$ & $\begin{array}{c}\text { Most } \\
\text { Internationalized } \\
\text { Countries } \\
\text { (Top 20 Percent) }\end{array}$ & Z-statistic & P-value \\
\hline Size & & & & & & \\
\hline Log of GDP (Million U.S. dollars) & 9.59 & 11.21 & 331 & 156 & -12.26 & 0.00 \\
\hline Income Level & & & & & & \\
\hline Log of GDP per capita (U.S. dollars) & 7.53 & 8.92 & 331 & 156 & -11.21 & 0.00 \\
\hline Macroeconomic Policies & & & & & & \\
\hline Log of (1+Inflation) & 0.09 & 0.07 & 300 & 156 & 2.78 & 0.01 \\
\hline Fiscal Surplus/GDP & 0.02 & 0.01 & 262 & 138 & 2.24 & 0.03 \\
\hline Openess & & & & & & \\
\hline Stock Market Liberalization & 1.00 & 1.00 & 300 & 132 & -4.74 & 0.00 \\
\hline Trade (Exports+Imports)/GDP & 0.90 & 0.59 & 323 & 156 & 6.99 & 0.00 \\
\hline Institutional Framework & & & & & & \\
\hline Law and Order & 4.00 & 5.00 & 27 & 13 & -1.31 & 0.19 \\
\hline Investor Protection & 5.30 & 5.70 & 26 & 12 & -1.37 & 0.17 \\
\hline
\end{tabular}

Countries with Activity in International Equity Markets - by Number of International Firms

\begin{tabular}{|c|c|c|c|c|c|c|}
\hline \multirow[b]{2}{*}{ Firm-Level Variables } & \multicolumn{2}{|c|}{ Median } & \multicolumn{2}{|c|}{ Number of Observations } & \multicolumn{2}{|c|}{ Mann-Whitney U-Test } \\
\hline & $\begin{array}{c}\text { Least } \\
\text { Internationalized } \\
\text { Countries } \\
\text { (Bottom 20 Percent) }\end{array}$ & $\begin{array}{c}\text { Most } \\
\text { Internationalized } \\
\text { Countries } \\
\text { (Top 20 Percent) }\end{array}$ & $\begin{array}{c}\text { Least } \\
\text { Internationalized } \\
\text { Countries } \\
\text { (Bottom 20 Percent) } \\
\end{array}$ & $\begin{array}{c}\text { Most } \\
\text { Internationalized } \\
\text { Countries } \\
\text { (Top 20 Percent) } \\
\end{array}$ & Z-statistic & P-value \\
\hline Size & & & & & & \\
\hline $\begin{array}{l}\text { Log of GDP (Million U.S. dollars) } \\
\text { Income Level }\end{array}$ & 9.99 & 11.83 & 167 & 167 & -11.08 & 0.00 \\
\hline $\begin{array}{l}\text { Log of GDP per capita (U.S. dollars) } \\
\text { Macroeconomic Policies }\end{array}$ & 7.13 & 9.93 & 167 & 167 & -14.61 & 0.00 \\
\hline Log of (1+Inflation) & 0.09 & 0.03 & 153 & 163 & 6.89 & 0.00 \\
\hline Fiscal Surplus/GDP & 0.03 & 0.02 & 149 & 163 & 4.73 & 0.00 \\
\hline Openess & & & & & & \\
\hline Stock Market Liberalization & 1.00 & 1.00 & 168 & 108 & -4.08 & 0.00 \\
\hline Trade (Exports+Imports)/GDP & 0.73 & 0.74 & 165 & 165 & -1.93 & 0.05 \\
\hline Institutional Framework & & & & & & \\
\hline Law and Order & 4.00 & 6.00 & 14 & 14 & -2.96 & 0.00 \\
\hline Investor Protection & 5.30 & 5.00 & 14 & 13 & -0.76 & 0.45 \\
\hline
\end{tabular}


Table 3a

Country-Level Regressions - All Countries

This table reports random-effects (linear) panel and Tobit estimates of the relation between country-level variables and the annual share of international firms over total firms in each country. The top panel presents regressions with a basic set of regressors; the bottom panel presents the same results for a wider set of regressors. International firms are those identified as having at least one active depositary receipt program, having raised equity capital in international markets, or being listed on the London Stock Exchange, NASDAQ, or NYSE. The United States and the United Kingdom are not included in the sample due to their classification as international financial centers. Z-statistics are in brackets. *, **, *** mean significant at ten, five, and one percent, respectively.

\begin{tabular}{|c|c|c|c|c|c|c|c|c|}
\hline & \multicolumn{8}{|c|}{ Number of International Firms over Total Firms - All Countries } \\
\hline & $\begin{array}{l}\text { Panel } \\
(1)\end{array}$ & $\begin{array}{l}\text { Tobit } \\
(2)\end{array}$ & $\begin{array}{c}\text { Panel } \\
(3) \\
\end{array}$ & $\begin{array}{c}\text { Tobit } \\
(4)\end{array}$ & $\begin{array}{c}\text { Panel } \\
(5)\end{array}$ & $\begin{array}{c}\text { Tobit } \\
(6)\end{array}$ & $\begin{array}{c}\text { Panel } \\
(7)\end{array}$ & $\begin{array}{c}\text { Tobit } \\
(8)\end{array}$ \\
\hline Log of GDP & $\begin{array}{l}0.027 \text { *** } \\
{[5.212]}\end{array}$ & $\begin{array}{l}0.061 \text { **** } \\
\text { [23.132] }\end{array}$ & $\begin{array}{l}0.028 \text { *** } \\
{[5.119]}\end{array}$ & $\begin{array}{l}0.044 \text { *** } \\
{[15.096]}\end{array}$ & $\begin{array}{l}0.052 \text { *** } \\
{[8.903]}\end{array}$ & $\begin{array}{l}0.078 \text { *** } \\
{[26.723]}\end{array}$ & $\begin{array}{l}0.055 \text { *** } \\
{[8.988]}\end{array}$ & $\begin{array}{l}0.096 \text { *** } \\
{[26.984]}\end{array}$ \\
\hline Log of GDP per Capita & $\begin{array}{l}0.038 * * * \\
{[5.933]}\end{array}$ & $\begin{array}{l}0.023 \text { *** } \\
{[9.340]}\end{array}$ & $\begin{array}{l}0.041 \text { *** } \\
{[6.032]}\end{array}$ & $\begin{array}{l}0.047 \\
{[16.906]}\end{array}$ & $\begin{array}{c}0.017 \text { ** } \\
{[2.402]}\end{array}$ & $\begin{array}{l}0.010 \\
{[4.503]}\end{array}$ & $\begin{array}{l}0.018 * * \\
{[2.444]}\end{array}$ & $\begin{array}{l}0.016 \text { *** } \\
{[7.025]}\end{array}$ \\
\hline Log (1+Inflation) & $\begin{array}{l}-0.019 * * * \\
{[3.578]}\end{array}$ & $\begin{array}{l}-0.065 * * * \\
{[7.103]}\end{array}$ & & & $\begin{array}{l}-0.022 * * * \\
{[3.974]}\end{array}$ & $\begin{array}{l}-0.049 * * * \\
{[5.300]}\end{array}$ & & \\
\hline Fiscal Surplus/GDP & & & $\begin{array}{l}0.226 \text { *** } \\
{[4.084]}\end{array}$ & $\begin{array}{l}0.470 \text { *** } \\
{[7.397]}\end{array}$ & & & $\begin{array}{l}0.128 * * \\
{[2.279]}\end{array}$ & $\begin{array}{l}0.263 \text { *** } \\
{[4.468]}\end{array}$ \\
\hline Trade (Exports+Imports)/GDP & & & & & $\begin{array}{l}0.157 \text { *** } \\
{[12.321]}\end{array}$ & $\begin{array}{l}0.199 \text { **** } \\
{[28.296]}\end{array}$ & $\begin{array}{l}0.164 \text { *** } \\
{[11.920]}\end{array}$ & $\begin{array}{l}0.214 \\
{[27.959}\end{array}$ \\
\hline Constant & $\begin{array}{l}-0.532 \text { *** } \\
{[13.773]}\end{array}$ & $\begin{array}{c}-0.820 \text { *** } \\
{[25.636]}\end{array}$ & $\begin{array}{l}-0.567 \text { *** } \\
{[14.277]}\end{array}$ & $\begin{array}{l}-0.797 \text { *** } \\
{[27.310]}\end{array}$ & $\begin{array}{l}-0.752 \text { *** } \\
{[16.864]}\end{array}$ & $\begin{array}{l}-1.032 \text { *** } \\
{[29.772]}\end{array}$ & $\begin{array}{l}-0.813 \text { *** } \\
{[17.826]}\end{array}$ & $\begin{array}{l}-1.313 * * * \\
{[30.915]}\end{array}$ \\
\hline Number of Observations & 1,133 & 1,133 & 1,064 & 1,064 & 1018 & 1018 & 962 & 962 \\
\hline \multirow[t]{3}{*}{ Number of Countries } & 104 & 104 & 100 & 100 & 88 & 88 & 86 & 86 \\
\hline & \multicolumn{8}{|c|}{ Number of International Firms over Total Firms - All Countries } \\
\hline & $\begin{array}{c}\text { Panel } \\
(1)\end{array}$ & $\begin{array}{l}\text { Tobit } \\
(2) \\
\end{array}$ & $\begin{array}{c}\text { Panel } \\
\text { (3) }\end{array}$ & $\begin{array}{c}\text { Tobit } \\
(4)\end{array}$ & $\begin{array}{c}\text { Panel } \\
(5)\end{array}$ & $\begin{array}{c}\text { Tobit } \\
(6)\end{array}$ & $\begin{array}{c}\text { Panel } \\
(7)\end{array}$ & $\begin{array}{c}\text { Tobit } \\
(8)\end{array}$ \\
\hline Log of GDP & $\begin{array}{l}0.039 \text { **** } \\
{[5.072]}\end{array}$ & $\begin{array}{l}0.043 * * * * \\
{[22.042]}\end{array}$ & $\begin{array}{l}0.038 \text { *** } \\
{[5.050]}\end{array}$ & $\begin{array}{l}0.043 \text { *** } \\
{[20.045]}\end{array}$ & $\begin{array}{l}0.042 \text { *** } \\
{[5.207]}\end{array}$ & $\begin{array}{l}0.048 * * * \\
{[21.121]}\end{array}$ & $\begin{array}{l}0.041 \text { *** } \\
{[5.118]}\end{array}$ & $\begin{array}{l}0.053 \text { *** } \\
{[23.141]}\end{array}$ \\
\hline Log of GDP per Capita & $\begin{array}{l}0.025 \\
{[2.907]}\end{array}$ & $\begin{array}{l}0.021 * * * \\
{[7.236]}\end{array}$ & $\begin{array}{l}0.018 * * \\
{[2.127]}\end{array}$ & $\begin{array}{l}0.019 \text { *** } \\
{[9.558]}\end{array}$ & $\begin{array}{l}0.028 * * * \\
{[2.977]}\end{array}$ & $\begin{array}{l}0.021 * * * \\
{[7.841]}\end{array}$ & $\begin{array}{l}0.019 * * \\
{[2.106]}\end{array}$ & $\begin{array}{l}0.024 \text { *** } \\
{[10.594]}\end{array}$ \\
\hline $\log (1+$ Inflation $)$ & $\begin{array}{l}-0.017 * * * \\
{[3.589]}\end{array}$ & $\begin{array}{l}-0.037 \text { *** } \\
{[5.080]}\end{array}$ & $\begin{array}{l}-0.018 * * * \\
{[3.861]}\end{array}$ & $\begin{array}{l}-0.049 * * * \\
{[6.707]}\end{array}$ & & & & \\
\hline Fiscal Surplus/GDP & & & & & $\begin{array}{r}0.033 \\
{[0.688]}\end{array}$ & $\begin{array}{l}0.105 * * \\
{[2.110]}\end{array}$ & $\begin{array}{r}0.064 \\
{[1.315]}\end{array}$ & $\begin{array}{l}0.171 \text { *** } \\
{[3.430]}\end{array}$ \\
\hline Stock Market Liberalization & $\begin{array}{l}0.017 \text { *** } \\
{[3.493]}\end{array}$ & $\begin{array}{l}0.053 * * * \\
{[9.250]}\end{array}$ & $\begin{array}{l}0.016 \text { *** } \\
{[3.474]}\end{array}$ & $\begin{array}{l}0.066 * * * \\
{[11.881]}\end{array}$ & $\begin{array}{l}0.020 * * * \\
{[3.800]}\end{array}$ & $\begin{array}{l}0.059 \text { *** } \\
{[9.963]}\end{array}$ & $\begin{array}{l}0.018 \text { *** } \\
{[3.654]}\end{array}$ & $\begin{array}{l}0.045 \text { *** } \\
{[8.286]}\end{array}$ \\
\hline Trade (Exports+Imports)/GDP & $\begin{array}{l}0.116 * * * \\
{[9.475]}\end{array}$ & $\begin{array}{l}0.107 \text { *** } \\
\text { [21.249] }\end{array}$ & $\begin{array}{l}0.127 \text { *** } \\
{[10.161]}\end{array}$ & $\begin{array}{l}0.137 \text { *** } \\
{[23.704]}\end{array}$ & $\begin{array}{l}0.129 * * * \\
{[9.612]}\end{array}$ & $\begin{array}{l}0.146 \text { *** } \\
{[26.924]}\end{array}$ & $\begin{array}{l}0.138 \text { *** } \\
{[10.243]}\end{array}$ & $\begin{array}{l}0.156 \\
{[24.494]}\end{array}$ \\
\hline Law and Order Index & $\begin{array}{l}-0.007 \text { *** } \\
{[3.395]}\end{array}$ & $\begin{array}{r}0.000 \\
{[0.075]}\end{array}$ & & & $\begin{array}{l}-0.008 * * * \\
{[3.680]}\end{array}$ & $\begin{array}{r}0.001 \\
{[0.480]}\end{array}$ & & \\
\hline Investor Protection Index & & & $\begin{array}{r}-0.006 \\
{[0.811]}\end{array}$ & $\begin{array}{l}-0.016 \text { **** } \\
{[11.841]}\end{array}$ & & & $\begin{array}{c}-0.008 \\
{[0.921]}\end{array}$ & $\begin{array}{l}-0.016 \text { *** } \\
{[11.428]}\end{array}$ \\
\hline Constant & $\begin{array}{c}-0.631 \text { *** } \\
{[12.538]}\end{array}$ & $\begin{array}{c}-0.693 \text { **** } \\
{[29.502]}\end{array}$ & $\begin{array}{l}-0.572 \text { **** } \\
{[9.107]}\end{array}$ & $\begin{array}{l}-0.645 \text { *** } \\
{[27.647]}\end{array}$ & $\begin{array}{c}-0.702 \text { **** } \\
{[13.263]}\end{array}$ & $\begin{array}{c}-0.798 \text { *** } \\
{[36.436]}\end{array}$ & $\begin{array}{l}-0.619 \text { *** } \\
{[9.544]}\end{array}$ & $\begin{array}{l}-0.781 \text { *** } \\
{[31.059]}\end{array}$ \\
\hline Number of Observations & 771 & 771 & 808 & 808 & 707 & 707 & 761 & 761 \\
\hline Number of Countries & 67 & 67 & 67 & 67 & 64 & 64 & 64 & 64 \\
\hline
\end{tabular}


Table 3b

\section{Country-Level Regressions - Developing Countries}

This table reports random-effects (linear) panel and Tobit estimates of the relation between country-level variables and the annual share of international firms over total firms in each country for the subsample of developing countries. The top panel presents regressions with a basic set of regressors; the bottom panel presents the same results for a wider set of regressors. International firms are those identified as having at least one active depositary receipt program, having raised equity capital in international markets, or being listed on the London Stock Exchange, NASDAQ, or NYSE. The United States and the United Kingdom are not included in the sample due to their classification as international financial centers. Z-statistics are in brackets. Countries are divided by income level following the classification of the World Development Indicators, World Bank at the beginning of the sample period (1989). *, **, **** mean significant at ten, five, and one percent, respectively.

\begin{tabular}{|c|c|c|c|c|c|c|c|c|}
\hline & \multicolumn{8}{|c|}{ Number of International Firms over Total Firms - Developing Countries } \\
\hline & $\begin{array}{c}\text { Panel } \\
(1)\end{array}$ & $\begin{array}{l}\text { Tobit } \\
(2)\end{array}$ & $\begin{array}{c}\text { Panel } \\
(3)\end{array}$ & $\begin{array}{c}\text { Tobit } \\
(4)\end{array}$ & $\begin{array}{c}\text { Panel } \\
(5)\end{array}$ & $\begin{array}{c}\text { Tobit } \\
(6)\end{array}$ & $\begin{array}{c}\text { Panel } \\
(7)\end{array}$ & $\begin{array}{c}\text { Tobit } \\
(8)\end{array}$ \\
\hline Log of GDP & $\begin{array}{l}0.022 * * * \\
{[5.074]}\end{array}$ & $\begin{array}{l}0.035 * * * \\
{[14.356]}\end{array}$ & $\begin{array}{l}0.024 * * * \\
{[5.196]}\end{array}$ & $\begin{array}{l}0.066 * * * \\
{[19.302]}\end{array}$ & $\begin{array}{l}0.037 \text { *** } \\
{[6.949]}\end{array}$ & $\begin{array}{l}0.055 \text { *** } \\
{[15.309]}\end{array}$ & $\begin{array}{l}0.040 * * * \\
{[7.141]}\end{array}$ & $\begin{array}{l}0.061 \\
{[17.377]}\end{array}$ \\
\hline Log of GDP per Capita & $\begin{array}{l}0.020 * * * \\
{[3.238]}\end{array}$ & $\begin{array}{l}0.058 \text { *** } \\
{[12.466]}\end{array}$ & $\begin{array}{l}0.024 * * * \\
{[3.628]}\end{array}$ & $\begin{array}{c}0.045 * * * \\
{[10.394]}\end{array}$ & $\begin{array}{r}0.008 \\
{[1.158]}\end{array}$ & $\begin{array}{l}0.038 \text { *** } \\
{[9.615]}\end{array}$ & $\begin{array}{c}0.014 * \\
{[1.820]}\end{array}$ & $\begin{array}{l}0.027 \text { *** } \\
{[6.610]}\end{array}$ \\
\hline Log (1+Inflation) & $\begin{array}{l}-0.023 * * * \\
{[5.150]}\end{array}$ & $\begin{array}{l}-0.071 \text { *** } \\
{[7.657]}\end{array}$ & & & $\begin{array}{l}-0.026 * * * \\
{[5.343]}\end{array}$ & $\begin{array}{l}-0.074 * * * \\
{[8.008]}\end{array}$ & & \\
\hline Fiscal Surplus/GDP & & & $\begin{array}{l}0.213 * * * * \\
{[3.232]}\end{array}$ & $\begin{array}{l}0.486 * * * \\
{[5.978]}\end{array}$ & & & $\begin{array}{l}0.167 * * \\
{[2.423]}\end{array}$ & $\begin{array}{l}0.483 * * * \\
{[5.099]}\end{array}$ \\
\hline Trade (Exports+Imports)/GDP & & & & & $\begin{array}{l}0.082 \text { *** } \\
{[6.257]}\end{array}$ & $\begin{array}{c}0.108 \text { *** } \\
{[8.364]}\end{array}$ & $\begin{array}{l}0.085 \text { *** } \\
{[5.824]}\end{array}$ & $\begin{array}{l}0.117 \text { *** } \\
{[9.406]}\end{array}$ \\
\hline Constant & $\begin{array}{l}-0.329 * * * \\
{[7.847]}\end{array}$ & $\begin{array}{c}-0.841 \text { *** } \\
{[19.287]}\end{array}$ & $\begin{array}{l}-0.381 \text { *** } \\
{[8.439]}\end{array}$ & $\begin{array}{c}-1.031 \text { *** } \\
{[22.885]}\end{array}$ & $\begin{array}{l}-0.459 * * * \\
{[9.084]}\end{array}$ & $\begin{array}{l}-0.882 \text { *** } \\
{[18.373]}\end{array}$ & $\begin{array}{l}-0.540 \text { *** } \\
{[10.031]}\end{array}$ & $\begin{array}{l}-0.891 \text { *** } \\
{[18.954]}\end{array}$ \\
\hline Number of Observations & 739 & 739 & 662 & 662 & 662 & 662 & 595 & 595 \\
\hline \multirow[t]{3}{*}{ Number of Countries } & 78 & 78 & 74 & 74 & 64 & 64 & 62 & 62 \\
\hline & \multicolumn{8}{|c|}{ Number of International Firms over Total Firms - Developing Countries } \\
\hline & $\begin{array}{c}\text { Panel } \\
(1)\end{array}$ & $\begin{array}{l}\text { Tobit } \\
(2) \\
\end{array}$ & $\begin{array}{c}\text { Panel } \\
\text { (3) } \\
\end{array}$ & $\begin{array}{c}\text { Tobit } \\
(4)\end{array}$ & $\begin{array}{c}\text { Panel } \\
(5) \\
\end{array}$ & $\begin{array}{c}\text { Tobit } \\
(6)\end{array}$ & $\begin{array}{c}\text { Panel } \\
(7) \\
\end{array}$ & $\begin{array}{c}\text { Tobit } \\
(8)\end{array}$ \\
\hline Log of GDP & $\begin{array}{l}0.030 \text { **** } \\
{[4.453]}\end{array}$ & $\begin{array}{l}0.035 \text { *** } \\
{[14.102]}\end{array}$ & $\begin{array}{l}0.029 * * * \\
{[4.388]}\end{array}$ & $\begin{array}{l}0.050 * * * \\
{[18.311]}\end{array}$ & $\begin{array}{l}0.035 * * * \\
{[4.720]}\end{array}$ & $\begin{array}{l}0.059 \text { *** } \\
{[19.309]}\end{array}$ & $\begin{array}{l}0.033 \text { *** } \\
{[4.533]}\end{array}$ & $\begin{array}{l}0.044 \text { *** } \\
{[15.136]}\end{array}$ \\
\hline Log of GDP per Capita & $\begin{array}{l}0.021 * * \\
{[2.542]}\end{array}$ & $\begin{array}{l}0.026 \text { *** } \\
{[8.160]}\end{array}$ & $\begin{array}{r}0.012 \\
{[1.455]}\end{array}$ & $\begin{array}{l}0.015 * * * \\
{[4.631]}\end{array}$ & $\begin{array}{l}0.024 * * * \\
{[2.706]}\end{array}$ & $\begin{array}{l}0.023 * * * \\
{[7.183]}\end{array}$ & $\begin{array}{r}0.014 \\
{[1.620]}\end{array}$ & $\begin{array}{l}0.021 \text { *** } \\
{[6.243]}\end{array}$ \\
\hline $\log (1+$ Inflation $)$ & $\begin{array}{l}-0.018 * * * \\
{[3.917]}\end{array}$ & $\begin{array}{l}-0.042 \text { *** } \\
{[5.696]}\end{array}$ & $\begin{array}{l}-0.019 \text { *** } \\
{[4.087]}\end{array}$ & $\begin{array}{l}-0.052 * * * \\
{[5.465]}\end{array}$ & & & & \\
\hline Fiscal Surplus/GDP & & & & & $\begin{array}{r}0.093 \\
{[1.337]}\end{array}$ & $\begin{array}{r}0.104 \\
{[1.383]}\end{array}$ & $\begin{array}{l}0.134 * \\
{[1.883]}\end{array}$ & $\begin{array}{l}0.228 * * * \\
{[3.137]}\end{array}$ \\
\hline Stock Market Liberalization & $\begin{array}{l}0.018 \text { *** } \\
{[3.460]}\end{array}$ & $\begin{array}{l}0.070 \text { *** } \\
{[8.163]}\end{array}$ & $\begin{array}{l}0.020 \text { *** } \\
{[3.820]}\end{array}$ & $\begin{array}{l}0.068 * * * \\
{[8.846]}\end{array}$ & $\begin{array}{l}0.018 \text { *** } \\
{[3.109]}\end{array}$ & $\begin{array}{l}0.057 \text { *** } \\
{[7.760]}\end{array}$ & $\begin{array}{l}0.019 \text { *** } \\
{[3.301]}\end{array}$ & $\begin{array}{l}0.070 \text { *** } \\
{[9.367]}\end{array}$ \\
\hline Trade (Exports+Imports)/GDP & $\begin{array}{l}0.075 \text { *** } \\
{[5.631]}\end{array}$ & $\begin{array}{l}0.083 \text { *** } \\
{[8.731]}\end{array}$ & $\begin{array}{l}0.082 \text { *** } \\
{[5.936]}\end{array}$ & $\begin{array}{l}0.102 \\
{[10.310]}\end{array}$ & $\begin{array}{l}0.086 \text { *** } \\
{[5.712]}\end{array}$ & $\begin{array}{l}0.086 \text { *** } \\
{[9.332]}\end{array}$ & $\begin{array}{l}0.092 \text { *** } \\
{[5.981]}\end{array}$ & $\begin{array}{l}0.111 \text { *** } \\
{[10.652]}\end{array}$ \\
\hline Law and Order Index & $\begin{array}{l}-0.007 * * * \\
{[3.236]}\end{array}$ & $\begin{array}{l}-0.009 * * * \\
{[3.613]}\end{array}$ & & & $\begin{array}{l}-0.008 * * * \\
{[3.377]}\end{array}$ & $\begin{array}{l}-0.005 * * \\
{[2.031]}\end{array}$ & & \\
\hline Investor Protection Index & & & $\begin{array}{r}-0.007 \\
{[0.933]}\end{array}$ & $\begin{array}{l}-0.012 * * * \\
{[5.450]}\end{array}$ & & & $\begin{array}{r}-0.007 \\
{[0.916]}\end{array}$ & $\begin{array}{l}-0.013 \text { *** } \\
{[6.133]}\end{array}$ \\
\hline Constant & $\begin{array}{l}-0.465 \text { *** } \\
{[8.199]}\end{array}$ & $\begin{array}{c}-0.610 \text { *** } \\
{[20.964]}\end{array}$ & $\begin{array}{l}-0.383 \text { *** } \\
{[5.612]}\end{array}$ & $\begin{array}{l}-0.708 \text { *** } \\
{[19.131]}\end{array}$ & $\begin{array}{l}-0.549 \text { *** } \\
{[8.830]}\end{array}$ & $\begin{array}{l}-0.817 \text { *** } \\
{[23.328]}\end{array}$ & $\begin{array}{l}-0.447 \text { *** } \\
{[6.155]}\end{array}$ & $\begin{array}{l}-0.684 \text { *** } \\
{[18.290]}\end{array}$ \\
\hline Number of Observations & 543 & 543 & 561 & 561 & 477 & 477 & 503 & 503 \\
\hline Number of Countries & 51 & 51 & 51 & 51 & 48 & 48 & 48 & 48 \\
\hline
\end{tabular}




\section{Table 4}

\section{Differences Across Firms and Countries}

This table reports the medians and the Mann-Whitney U-test of equality of medians for different characteristics of domestic firms and international firms over the whole sample period (1989-2000). The top panel reports median values of the variables of interest, the middle panel reports tests of equality of medians between domestic and international firms for the different country groupings, and the bottom panel reports tests of equality of medians between developed and developed countries across the different types of firms. The number of observations is reported in parentheses in the top panel. The sample includes only those firms used in the regressions. The United States and the United Kingdom are not included in the sample due to their classification as international financial centers. International firms are those identified as having at least one active depositary receipt program, having raised equity capital in international markets, or being listed on the London Stock Exchange, NASDAQ, or NYSE at any point during the sample period. Countries are divided by income level following the classification of the World Development Indicators, World Bank at the beginning of the sample period (1989).

\section{Median Values}

\begin{tabular}{|c|c|c|c|c|c|c|}
\hline \multirow[b]{2}{*}{ Firm-Level Variables } & \multicolumn{3}{|c|}{ Domestic Firms } & \multicolumn{3}{|c|}{ International Firms } \\
\hline & All Countries & $\begin{array}{r}\text { Developed } \\
\text { Countries } \\
\end{array}$ & $\begin{array}{c}\text { Developing } \\
\text { Countries }\end{array}$ & All Countries & $\begin{array}{l}\text { Developed } \\
\text { Countries } \\
\end{array}$ & $\begin{array}{c}\text { Developing } \\
\text { Countries }\end{array}$ \\
\hline $\begin{array}{l}\text { Size } \\
\text { Total Assets (Million U.S. dollars) }\end{array}$ & $\begin{array}{c}275.3 \\
(64,480)\end{array}$ & $\begin{array}{c}316.3 \\
(49,890)\end{array}$ & $\begin{array}{c}164.7 \\
(14,590)\end{array}$ & $\begin{array}{c}1,654.1 \\
(10,323)\end{array}$ & $\begin{array}{l}2,454.1 \\
(6,801)\end{array}$ & $\begin{array}{c}916.1 \\
(3,522)\end{array}$ \\
\hline $\begin{array}{l}\text { Growth } \\
\text { Log (1+Sales Growth) }\end{array}$ & $\begin{array}{c}0.048 \\
(64,480)\end{array}$ & $\begin{array}{c}0.046 \\
(49,890)\end{array}$ & $\begin{array}{c}0.058 \\
(14,590)\end{array}$ & $\begin{array}{c}0.081 \\
(10,323)\end{array}$ & $\begin{array}{c}0.079 \\
(3,522)\end{array}$ & $\begin{array}{c}0.087 \\
(6,801)\end{array}$ \\
\hline $\begin{array}{l}\text { Performance } \\
\text { Return on Assets }\end{array}$ & $\begin{array}{c}0.037 \\
(64,480)\end{array}$ & $\begin{array}{c}0.031 \\
(49,890)\end{array}$ & $\begin{array}{c}0.065 \\
(14,590)\end{array}$ & $\begin{array}{c}0.054 \\
(10,323)\end{array}$ & $\begin{array}{c}0.047 \\
(3,522)\end{array}$ & $\begin{array}{c}0.073 \\
(6,801)\end{array}$ \\
\hline $\begin{array}{l}\text { Others } \\
\text { Foreign Sales / Total Sales }\end{array}$ & $\begin{array}{c}0.000 \\
(43,109)\end{array}$ & $\begin{array}{c}0.000 \\
(33,858)\end{array}$ & $\begin{array}{c}0.000 \\
(9,251)\end{array}$ & $\begin{array}{c}0.29 \\
(6,925)\end{array}$ & $\begin{array}{c}0.44 \\
(5,081)\end{array}$ & $\begin{array}{c}0.00 \\
(1,844)\end{array}$ \\
\hline
\end{tabular}

Differences in Median Values between International and Domestic Firms (Mann-Whitney U-test)

\begin{tabular}{|c|c|c|c|c|c|c|}
\hline \multirow{2}{*}{ Firm-Level Variables } & \multicolumn{2}{|c|}{ All Countries } & \multicolumn{2}{|c|}{ Developed Countries } & \multicolumn{2}{|c|}{ Developing Countries } \\
\hline & Z-statistic & P-value & Z-statistic & P-value & Z-statistic & P-value \\
\hline Size & & & & & & \\
\hline Total Assets (Million U.S. dollars) & 82.78 & 0.00 & 69.76 & 0.00 & 52.14 & 0.00 \\
\hline Growth & & & & & & \\
\hline Log (1+Sales Growth) & 14.87 & 0.00 & 13.12 & 0.00 & 6.42 & 0.00 \\
\hline Performance & & & & & & \\
\hline Return on Assets & 25.87 & 0.00 & 22.23 & 0.00 & 4.73 & 0.00 \\
\hline Others & & & & & & \\
\hline Foreign Sales / Total Sales & 55.50 & 0.00 & 60.54 & 0.00 & 17.26 & 0.00 \\
\hline
\end{tabular}

Differences in Median Values between Firms from Developed and Developing Countries (Mann-Whitney U-test)

\begin{tabular}{|c|c|c|c|c|}
\hline \multirow{2}{*}{ Firm-Level Variables } & \multicolumn{2}{|c|}{ Domestic Firms } & \multicolumn{2}{|c|}{ International Firms } \\
\hline & Z-statistic & P-value & Z-statistic & P-value \\
\hline$\overline{\text { Size }}$ & & & & \\
\hline Total Assets (Million U.S. dollars) & 41.92 & 0.00 & 20.71 & 0.00 \\
\hline Growth & & & & \\
\hline Log (1+Sales Growth) & -3.39 & 0.00 & -0.91 & 0.36 \\
\hline Performance & & & & \\
\hline Return on Assets & -56.44 & 0.00 & -18.02 & 0.00 \\
\hline Others & & & & \\
\hline Foreign Sales / Total Sales & 61.85 & 0.00 & 42.78 & 0.00 \\
\hline
\end{tabular}


Table 5

\section{Probit Regressions}

This table reports Probit estimates of the probability of becoming an international firm. The dependent variable is a dummy variable that equals zero if the firm is domestic in the entire sample, and one if the firm is domestic in 1993 and becomes international afterwards. The top panel includes country dummies to account for country-specific effects, while the bottom panel includes the following country variables, which are not reported: $\log$ of GDP, $\log$ of GDP per capita, trade to GDP, inflation, stock market liberalization, and investor protection. The figures show the marginal probabilities, i.e., the change in the probability for an infinitesimal change in each independent continuous variable. The values for the independent variables are 1993 values. International firms are those identified as having at least one active depositary receipt program, having raised equity capital in international markets, or being listed on the London Stock Exchange, NASDAQ, or NYSE. The United States and the United Kingdom are not included in the sample due to their classification as international financial centers. Standard errors are adjusted for clustering on companies; they consider the panel structure of the data. Countries are divided by income level following the classification of the World Development Indicators, World Bank at the beginning of the sample period (1989). Robust z-statistics are in brackets. *,**,*** mean significant at ten, five, and one percent, respectively.

\begin{tabular}{|c|c|c|c|c|c|c|}
\hline \multirow[b]{4}{*}{ Size } & \multicolumn{6}{|c|}{ Marginal Probability of Becoming an International Firm - with Country Dummies } \\
\hline & \multicolumn{2}{|c|}{ All Countries } & \multicolumn{2}{|c|}{ Developed Countries } & \multicolumn{2}{|c|}{ Developing Countries } \\
\hline & $(1)$ & $(2)$ & (3) & $(4)$ & $(5)$ & $(6)$ \\
\hline & & & & & & \\
\hline Log of Total Assets & $\begin{array}{l}0.014 * * * \\
{[14.285]}\end{array}$ & $\begin{array}{l}0.010 \text { *** } \\
{[11.799]}\end{array}$ & $\begin{array}{l}0.010 * * * \\
{[11.438]}\end{array}$ & $\begin{array}{l}0.008 * * * \\
{[9.850]}\end{array}$ & $\begin{array}{l}0.039 * * * \\
{[9.470]}\end{array}$ & $\begin{array}{l}0.030 * * * \\
{[7.096]}\end{array}$ \\
\hline \multicolumn{7}{|l|}{ Growth } \\
\hline Log $(1+$ Sales Growth $)$ & $\begin{array}{l}0.008 * * \\
{[2.425]}\end{array}$ & $\begin{array}{l}0.009 * * * \\
{[3.727]}\end{array}$ & $\begin{array}{r}0.005 \\
{[1.601]}\end{array}$ & $\begin{array}{l}0.010 * * \\
{[2.463]}\end{array}$ & $\begin{array}{l}0.019 * \\
{[1.677]}\end{array}$ & $\begin{array}{l}0.021 * * * \\
{[3.233]}\end{array}$ \\
\hline \multicolumn{7}{|l|}{ Performance } \\
\hline Return on Assets & $\begin{array}{r}0.005 \\
{[0.864]}\end{array}$ & $\begin{array}{c}0.011 * \\
{[1.708]}\end{array}$ & $\begin{array}{c}0.007 \\
{[0.395]}\end{array}$ & $\begin{array}{r}0.006 \\
{[0.276]}\end{array}$ & $\begin{array}{r}0.009 \\
{[0.533]}\end{array}$ & $\begin{array}{c}0.027 * \\
{[1.763]}\end{array}$ \\
\hline \multicolumn{7}{|l|}{ Others } \\
\hline Foreign Sales to Total Sales & & $\begin{array}{l}0.017 \text { *** } \\
{[3.795]}\end{array}$ & & $\begin{array}{l}0.013 * * * \\
{[3.441]}\end{array}$ & & $\begin{array}{c}0.071 * \\
{[1.680]}\end{array}$ \\
\hline Country Variables & No & No & No & No & No & No \\
\hline Country Dummies & Yes & Yes & Yes & Yes & Yes & Yes \\
\hline Industry Dummies & Yes & Yes & Yes & Yes & Yes & Yes \\
\hline Number of Observations & 5,254 & 3,344 & 4,112 & 2,773 & 1,142 & 571 \\
\hline Number of Countries & 39 & 39 & 19 & 19 & 20 & 20 \\
\hline Number of International Firms & 303 & 186 & 178 & 129 & 125 & 57 \\
\hline \multirow[t]{4}{*}{ Pseudo R-squared } & 0.332 & 0.375 & 0.322 & 0.368 & 0.31 & 0.383 \\
\hline & \multicolumn{6}{|c|}{ Marginal Probability of Becoming an International Firm - with Country Variables } \\
\hline & \multicolumn{2}{|c|}{ All Countries } & \multicolumn{2}{|c|}{ Developed Countries } & \multicolumn{2}{|c|}{ Developing Countries } \\
\hline & $(1)$ & $(2)$ & $(3)$ & $(4)$ & $(5)$ & $(6)$ \\
\hline $\begin{array}{l}\text { Size } \\
\text { Log of Total Assets }\end{array}$ & $\begin{array}{r}0.018 * * * \\
{[13.353]}\end{array}$ & $\begin{array}{l}0.012 \text { *** } \\
{[11.156]}\end{array}$ & $\begin{array}{l}0.010 * * * \\
{[9.528]}\end{array}$ & $\begin{array}{l}0.007 * * * \\
{[8.523]}\end{array}$ & $\begin{array}{l}0.042 \text { *** } \\
{[10.399]}\end{array}$ & $\begin{array}{l}0.024 * * * \\
{[7.694]}\end{array}$ \\
\hline \multicolumn{7}{|l|}{ Growth } \\
\hline Log (1+Sales Growth) & $\begin{array}{l}0.011 * * * \\
{[2.605]}\end{array}$ & $\begin{array}{l}0.010 * * * \\
{[3.060]}\end{array}$ & $\begin{array}{l}0.008 * * * \\
{[2.664]}\end{array}$ & $\begin{array}{l}0.010 * * \\
{[2.353]}\end{array}$ & $\begin{array}{r}0.020 \\
{[1.555]}\end{array}$ & $\begin{array}{l}0.016 * * * \\
{[3.192]}\end{array}$ \\
\hline \multicolumn{7}{|l|}{ Performance } \\
\hline Return on Assets & $\begin{array}{r}0.003 \\
{[0.306]}\end{array}$ & $\begin{array}{r}0.002 \\
{[0.185]}\end{array}$ & $\begin{array}{c}-0.009 \\
{[0.359]}\end{array}$ & $\begin{array}{c}-0.007 \\
{[0.320]}\end{array}$ & $\begin{array}{r}0.011 \\
{[0.573]}\end{array}$ & $\begin{array}{r}0.016 \\
{[1.268]}\end{array}$ \\
\hline $\begin{array}{l}\text { Others } \\
\text { Foreign Sales to Total Sales }\end{array}$ & & $\begin{array}{l}0.031 * * * \\
{[5.462]}\end{array}$ & & $\begin{array}{l}0.016 \text { *** } \\
{[4.027]}\end{array}$ & & $\begin{array}{r}0.050 \\
{[1.560]}\end{array}$ \\
\hline $\begin{array}{l}\text { Country Variables } \\
\text { Country Dummies } \\
\text { Industry Dummies }\end{array}$ & $\begin{array}{l}\text { Yes } \\
\text { No } \\
\text { Yes }\end{array}$ & $\begin{array}{l}\text { Yes } \\
\text { No } \\
\text { Yes }\end{array}$ & $\begin{array}{r}\text { Yes } \\
\text { No } \\
\text { Yes }\end{array}$ & $\begin{array}{r}\text { Yes } \\
\text { No } \\
\text { Yes }\end{array}$ & $\begin{array}{r}\text { Yes } \\
\text { No } \\
\text { Yes }\end{array}$ & $\begin{array}{l}\text { Yes } \\
\text { No } \\
\text { Yes }\end{array}$ \\
\hline Number of Observations & 4,620 & 3,227 & 3,489 & 2,544 & 1,131 & 683 \\
\hline Number of Countries & 31 & 31 & 12 & 12 & 19 & 19 \\
\hline Number of International Firms & 254 & 153 & 134 & 99 & 120 & 54 \\
\hline Pseudo R-squared & 0.257 & 0.302 & 0.302 & 0.352 & 0.264 & 0.35 \\
\hline
\end{tabular}




\section{Table 6}

\section{Cox Regressions}

This table reports Cox estimates of the hazard ratio of becoming an international firm between 1989 and 2000 . The dependent variable is a dummy that takes the value one in the year of internationalization, and zero otherwise. After internationalization, observations are excluded from the estimation. The top panel includes country dummies to account for country-specific effects, while the bottom panel includes the following country variables, which are not reported: log of GDP, log of GDP per capita, trade to GDP, inflation, stock market liberalization, and investor protection. International firms are those identified as having at least one active depositary receipt program, having raised equity capital in international markets, or being listed on the London Stock Exchange, NASDAQ, or NYSE. The United States and the United Kingdom are not included in the sample due to their classification as international financial centers. All explanatory variables are lagged, with the exception of the dummy variables and the country-level variables. Reported estimates are exponentiated coefficients. Standard errors are adjusted for clustering on companies; they consider the panel structure of the data. Countries are divided by income level following the classification of the World Development Indicators, World Bank at the beginning of the sample period (1989). Robust $\mathrm{z}$-statistics are in brackets. *, **, *** mean significant at ten, five, and one percent, respectively.

\begin{tabular}{|c|c|c|c|c|c|c|}
\hline \multirow[b]{4}{*}{ Size } & \multicolumn{6}{|c|}{ Hazard Ratio - with Country Dummies } \\
\hline & \multicolumn{2}{|c|}{ All Countries } & \multicolumn{2}{|c|}{ Developed Countries } & \multicolumn{2}{|c|}{ Developing Countries } \\
\hline & $(1)$ & $(2)$ & $(3)$ & $(4)$ & $(5)$ & $(6)$ \\
\hline & & & & & & \\
\hline Log of Total Assets & $\begin{array}{r}1.716 \text { *** } \\
{[17.720]}\end{array}$ & $\begin{array}{l}1.657 \text { *** } \\
{[12.895]}\end{array}$ & $\begin{array}{l}1.719 \text { *** } \\
{[14.078]}\end{array}$ & $\begin{array}{l}1.670 * * * \\
{[10.909]}\end{array}$ & $\begin{array}{l}1.730 \text { *** } \\
{[11.140]}\end{array}$ & $\begin{array}{l}1.637 * * * \\
{[7.388]}\end{array}$ \\
\hline \multicolumn{7}{|l|}{ Growth } \\
\hline Log (1+Sales Growth) & $\begin{array}{l}1.306 \text { *** } \\
{[4.898]}\end{array}$ & $\begin{array}{l}1.252 \text { *** } \\
{[3.256]}\end{array}$ & $\begin{array}{l}1.339 * * * \\
{[3.859]}\end{array}$ & $\begin{array}{l}1.244 \text { *** } \\
{[2.730]}\end{array}$ & $\begin{array}{r}1.171 \\
{[1.205]}\end{array}$ & $\begin{array}{r}1.062 \\
{[0.263]}\end{array}$ \\
\hline \multicolumn{7}{|l|}{ Performance } \\
\hline Return on Assets & $\begin{array}{c}1.375 \text { ** } \\
{[2.186]}\end{array}$ & $\begin{array}{l}1.750 * * \\
{[2.539]}\end{array}$ & $\begin{array}{c}1.111 \\
{[0.256]}\end{array}$ & $\begin{array}{r}2.738 \\
{[2.341]}\end{array}$ & $\begin{array}{r}1.370 \\
{[2.011]}\end{array}$ & $\begin{array}{r}1.249 \\
{[0.953]}\end{array}$ \\
\hline \multicolumn{7}{|l|}{ Others } \\
\hline Foreign Sales to Total Sales & & $\begin{array}{l}3.198 * * * \\
{[5.654]}\end{array}$ & & $\begin{array}{l}2.677 \text { *** } \\
{[4.286]}\end{array}$ & & $\begin{array}{l}5.650 * * * \\
{[3.664]}\end{array}$ \\
\hline $\begin{array}{l}\text { Country Variables } \\
\text { Country Dummies } \\
\text { Industry Dummies } \\
\text { Year Dummies }\end{array}$ & $\begin{array}{l}\text { No } \\
\text { Yes } \\
\text { Yes } \\
\text { Yes }\end{array}$ & $\begin{array}{l}\text { No } \\
\text { Yes } \\
\text { Yes } \\
\text { Yes }\end{array}$ & $\begin{array}{l}\text { No } \\
\text { Yes } \\
\text { Yes } \\
\text { Yes }\end{array}$ & $\begin{array}{l}\text { No } \\
\text { Yes } \\
\text { Yes } \\
\text { Yes }\end{array}$ & $\begin{array}{l}\text { No } \\
\text { Yes } \\
\text { Yes } \\
\text { Yes }\end{array}$ & $\begin{array}{l}\text { No } \\
\text { Yes } \\
\text { Yes } \\
\text { Yes }\end{array}$ \\
\hline Number of Observations & 64,172 & 43,226 & 49,186 & 33,890 & 14,986 & 9,336 \\
\hline Number of Countries & 65 & 57 & 23 & 22 & 42 & 35 \\
\hline Number of International Firms & 2,145 & 1,310 & 362 & 286 & 237 & 125 \\
\hline \multirow[t]{4}{*}{ Pseudo R-squared } & 0.114 & 0.128 & 0.117 & 0.13 & 0.119 & 0.167 \\
\hline & \multicolumn{6}{|c|}{ Hazard Ratio - with Country Variables } \\
\hline & \multicolumn{2}{|c|}{ All Countries } & \multicolumn{2}{|c|}{ Developed Countries } & \multicolumn{2}{|c|}{ Developing Countries } \\
\hline & $(1)$ & $(2)$ & $(3)$ & $(4)$ & $(5)$ & $(6)$ \\
\hline \multicolumn{7}{|l|}{ Size } \\
\hline Log of Total Assets & $\begin{array}{l}1.717 \text { *** } \\
{[16.904]}\end{array}$ & $\begin{array}{l}1.658 \text { *** } \\
{[12.448]}\end{array}$ & $\begin{array}{l}1.631 \text { *** } \\
{[11.113]}\end{array}$ & $\begin{array}{l}1.547 \text { *** } \\
{[8.444]}\end{array}$ & $\begin{array}{l}1.779 \text { *** } \\
{[12.673]}\end{array}$ & $\begin{array}{l}1.833 * * * \\
{[8.551]}\end{array}$ \\
\hline \multicolumn{7}{|l|}{ Growth } \\
\hline Log (1+Sales Growth) & $\begin{array}{l}1.368 \text { *** } \\
{[5.707]}\end{array}$ & $\begin{array}{l}1.356 \text { *** } \\
{[4.303]}\end{array}$ & $\begin{array}{l}1.384 * * * \\
{[4.328]}\end{array}$ & $\begin{array}{l}1.274 \text { *** } \\
{[3.215]}\end{array}$ & $\begin{array}{r}1.365 * * * \\
{[2.928]}\end{array}$ & $\begin{array}{r}1.322 \\
{[1.582]}\end{array}$ \\
\hline \multicolumn{7}{|l|}{ Performance } \\
\hline Return on Assets & $\begin{array}{r}1.410 \text { ** } \\
{[2.450]}\end{array}$ & $\begin{array}{l}1.902 \text { ** } \\
{[2.294]}\end{array}$ & $\begin{array}{r}0.856 \\
{[0.266]}\end{array}$ & $\begin{array}{r}2.323 \\
{[1.848]}\end{array}$ & $\begin{array}{l}1.574 * * * \\
{[3.300]}\end{array}$ & $\begin{array}{r}1.779 \\
{[2.078]}\end{array}$ \\
\hline \multicolumn{7}{|l|}{ Others } \\
\hline Foreign Sales to Total Sales & & $\begin{array}{l}2.454 \text { *** } \\
{[4.985]}\end{array}$ & & $\begin{array}{l}4.048 * * * \\
{[5.493]}\end{array}$ & & $\begin{array}{l}2.433 * * * \\
{[3.070]}\end{array}$ \\
\hline Country Variables & Yes & Yes & Yes & Yes & Yes & Yes \\
\hline Country Dummies & No & No & No & No & No & No \\
\hline Industry Dummies & Yes & Yes & Yes & Yes & Yes & Yes \\
\hline Year Dummies & Yes & Yes & Yes & Yes & Yes & Yes \\
\hline Number of Observations & 55,415 & 37,704 & 40,912 & 28,621 & 14,503 & 9,083 \\
\hline Number of Countries & 50 & 46 & 14 & 14 & 36 & 32 \\
\hline Number of International Firms & 1,753 & 1,032 & 258 & 205 & 211 & 107 \\
\hline Pseudo R-squared & 0.081 & 0.097 & 0.115 & 0.135 & 0.085 & 0.121 \\
\hline
\end{tabular}


Table 7

\section{Differences in Firm Characteristics Between International and Domestic Firms}

This table reports panel regressions where the dependent variables are total assets, sales growth, return on assets, and foreign sales to total sales for each firm. The after internationalization dummy equals one on and after the year when a firm becomes international and zero otherwise (it becomes zero if a firm is delisted). The before internationalization dummy equals one for all the years before the year a firm becomes international and zero otherwise. For domestic firms, these dummies always equal zero value. International firms are those identified as having at least one active depositary receipt program, having raised equity capital in international markets, or being listed on the London Stock Exchange, NYSE, or NASDAQ. The United States and the United Kingdom are excluded from the sample since they are considered financial centers. A constant is estimated but not reported. Standard errors are adjusted for clustering on companies; they consider the panel structure of the data. Absolute values of t-statistics are in brackets. *,**, *** mean significance at ten, five, and one percent, respectively.

\begin{tabular}{lcccc}
\hline & \multicolumn{4}{c}{ Firm Characteristics } \\
\cline { 2 - 5 } & Total Assets & Sales Growth & $\begin{array}{c}\text { Return on } \\
\text { Assets }\end{array}$ & $\begin{array}{c}\text { Foreign Sales to } \\
\text { Total Sales }\end{array}$ \\
\cline { 2 - 5 } & \multicolumn{1}{c}{$(1)$} & $(2)$ & $(3)$ & $(4)$ \\
\hline & $3,666.7 * * *$ & $0.060 * * *$ & $0.021 * * *$ & $0.116 * * *$ \\
Before Internationalization Dummy (a) & {$[9.516]$} & {$[5.064]$} & {$[2.933]$} & {$[10.143]$} \\
After Internationalization Dummy (b) & $5,858.1 * * *$ & $0.022 * * *$ & 0.001 & $0.146 * * *$ \\
& {$[14.479]$} & {$[4.387]$} & {$[0.296]$} & {$[17.442]$} \\
Country Dummies & & & & Yes \\
Industry Dummies & Yes & Yes & Yes & Yes \\
Year Dummies & Yes & Yes & Yes & Yes \\
Number of Observations & Yes & Yes & 74,803 & 50,034 \\
Number of Firms & 74,803 & 74,803 & 10,154 & 8,048 \\
Before Int. Dummy - After Int. Dummy, (b)-(a) & 10,154 & 10,154 & -0.021 & 0.030 \\
Test (b)-(a)=0; P-value & 2,191 & -0.038 & 0.006 & 0.002 \\
\hline
\end{tabular}




\section{Appendix Table 1}

\section{Series Description and Data Sources}

This table shows the description of the series used and the data sources. The data cover the period 1989-2000.

\begin{tabular}{|c|c|c|}
\hline Series Names & Description & Source \\
\hline $\begin{array}{l}\text { Country-Level } \\
\text { GDP at market prices (current U.S. } \\
\text { dollars) }\end{array}$ & $\begin{array}{l}\text { Gross domestic product (GDP) at purchaser prices. GDP data is converted from domestic currencies using yearly average } \\
\text { official exchange rates. For a few countries where the official exchange rate does not reflect the rate effectively applied to } \\
\text { actual foreign exchange transactions, an alternative conversion factor is used. }\end{array}$ & World Bank: World Development Indicators \\
\hline $\begin{array}{l}\text { GDP per capita at market prices } \\
\text { (current U.S. dollars) }\end{array}$ & Gross domestic product divided by mid-year population. & World Bank: World Development Indicators \\
\hline $\begin{array}{l}\text { Inflation, consumer prices (percent } \\
\text { per year) }\end{array}$ & Inflation as measured by the consumer price index. & World Bank: World Development Indicators \\
\hline Fiscal surplus & $\begin{array}{l}\text { Overall budget balance, defined as current and capital revenue and official grants received, less total expenditure and } \\
\text { lending minus repayments. Data are for central government only. }\end{array}$ & World Bank: World Development Indicators \\
\hline Stock market liberalization & $\begin{array}{l}\text { Takes the value one after the year of full stock market liberalization as indicated by combining liberalization dates of } \\
\text { Bekaert et al. (2005), Kaminsky and Schmukler (2003), and Vinhas de Souza (2005). }\end{array}$ & $\begin{array}{l}\text { Bekaert et al. (2005), Kaminsky and Schmukler (2003), and } \\
\text { Vinhas de Souza (2005). }\end{array}$ \\
\hline Trade (exports plus imports) & Sum of exports and imports of goods and services, expressed in current U.S. dollars. & World Bank: World Development Indicators \\
\hline Law and order Index & Law and order index. & International Country Risk Guide (ICRG) \\
\hline Investor protection index & Investor protection index. & World Bank: Doing Business \\
\hline \multicolumn{2}{|l|}{ Firm-Level } & Worldscope \\
\hline Two-year average sales growth & Geometric average annual sales growth over the last two years. Sales are expressed in U.S. dollars. & Worldscope \\
\hline Return on assets & $\begin{array}{l}\text { Sum of net income (before preferred dividends) and interest expenses on capitalized debt (after tax), over last year's total } \\
\text { assets. }\end{array}$ & Worldscope \\
\hline Foreign sales to total sales & Annual international sales over net sales or revenues. & Worldscope \\
\hline
\end{tabular}


Appendix Table 2

Number of International and Domestic Firms by Country

This table reports, by country, the number of international and domestic firms used in the regressions. International firms are those identified as having at least one active depositary receipt program, having raised equity capital in international markets, or being listed on the London Stock Exchange, NASDAQ, or NYSE. The United States and the United Kingdom are not included in the sample due to their classification as international financial centers. Countries are divided by income level following the classification of the World Development Indicators, World Bank at the beginning of the sample period (1989).

\begin{tabular}{|c|c|c|c|c|}
\hline \multicolumn{5}{|c|}{ Developing Countries } \\
\hline & Country & Number of Firms & \begin{tabular}{|c|} 
Number of \\
International Firms
\end{tabular} & $\begin{array}{c}\text { Number of } \\
\text { Domestic Firms }\end{array}$ \\
\hline 1 & Argentina & 154 & 25 & 129 \\
\hline 2 & Armenia & 95 & - & 95 \\
\hline 3 & Azerbaijan & 2 & - & 2 \\
\hline 4 & Bahrain & 41 & - & 41 \\
\hline 5 & Bangladesh & 211 & - & 211 \\
\hline 6 & Barbados & 18 & - & 18 \\
\hline 7 & Bhutan & 13 & - & 13 \\
\hline 8 & Bolivia & 18 & - & 18 \\
\hline 9 & Botswana & 15 & - & 15 \\
\hline 10 & Brazil & 549 & 71 & 478 \\
\hline 11 & Bulgaria & 831 & 3 & 828 \\
\hline 12 & Chile & 312 & 27 & 285 \\
\hline 13 & China & 1,055 & 105 & 950 \\
\hline 14 & Colombia & 155 & 10 & 145 \\
\hline 15 & Costa Rica & 22 & - & 22 \\
\hline 16 & Cote d'Ivoire & 38 & - & 38 \\
\hline 17 & Croatia & 62 & 3 & 59 \\
\hline 18 & Czech Republic & 169 & 5 & 164 \\
\hline 19 & Dominican Republic & 6 & - & 6 \\
\hline 20 & Ecuador & 32 & 4 & 28 \\
\hline 21 & Egypt & 1,041 & 8 & 1,033 \\
\hline 22 & El Salvador & 40 & - & 40 \\
\hline 23 & Estonia & 27 & 2 & 25 \\
\hline 24 & Fiji & 9 & - & 9 \\
\hline 25 & Ghana & 23 & 1 & 22 \\
\hline 26 & Greece & 294 & 13 & 281 \\
\hline 27 & Guatemala & 5 & - & 5 \\
\hline 28 & Honduras & 71 & - & 71 \\
\hline 29 & Hungary & 94 & 28 & 66 \\
\hline 30 & India & 5,936 & 73 & 5,863 \\
\hline 31 & Indonesia & 290 & 13 & 277 \\
\hline 32 & Iran & 292 & - & 292 \\
\hline 33 & Jamaica & 50 & 4 & 46 \\
\hline 34 & Jordan & 154 & 2 & 152 \\
\hline 35 & Kazakhstan & 21 & 4 & 17 \\
\hline 36 & Kenya & 58 & 1 & 57 \\
\hline 37 & Korea & 1,219 & 41 & 1,178 \\
\hline 39 & Latvia & 72 & 2 & 70 \\
\hline 40 & Lebanon & 12 & - & 12 \\
\hline 41 & Lithuania & 58 & 4 & 54 \\
\hline 42 & Macedonia & 2 & - & 2 \\
\hline 43 & Malaysia & 772 & 15 & 757 \\
\hline 44 & Malta & 8 & 1 & 7 \\
\hline 45 & Mauritius & 45 & 4 & 41 \\
\hline 47 & Mexico & 270 & 82 & 188 \\
\hline 48 & Moldova & 58 & - & 58 \\
\hline 49 & Mongolia & 418 & - & 418 \\
\hline 50 & Morocco & 56 & 1 & 55 \\
\hline 51 & Namibia & 14 & - & 14 \\
\hline 52 & Nepal & 108 & - & 108 \\
\hline 53 & Nigeria & 195 & 1 & 194 \\
\hline 54 & Oman & 140 & - & 140 \\
\hline 55 & Pakistan & 769 & 4 & 765 \\
\hline 56 & Panama & 31 & - & 31 \\
\hline 57 & Paraguay & 55 & - & 55 \\
\hline 59 & Peru & 254 & 12 & 242 \\
\hline 60 & Philippines & 243 & 17 & 226 \\
\hline 61 & Poland & 241 & 20 & 221 \\
\hline 62 & Portugal & 136 & 11 & 125 \\
\hline 63 & Romania & 5,827 & 2 & 5,825 \\
\hline 64 & Russia & 258 & 51 & 207 \\
\hline 65 & Saudi Arabia & 73 & - & 73 \\
\hline 66 & Serbia and Montenegro & 20 & - & 20 \\
\hline
\end{tabular}


Appendix Table 2

Number of International and Domestic Firms by Country

This table reports, by country, the number of international and domestic firms used in the regressions. International firms are those identified as having at least one active depositary receipt program, having raised equity capital in international markets, or being listed on the London Stock Exchange, NASDAQ, or NYSE. The United States and the United Kingdom are not included in the sample due to their classification as international financial centers. Countries are divided by income level following the classification of the World Development Indicators, World Bank at the beginning of the sample period (1989).

\begin{tabular}{c|l|c|c|c}
\hline \multicolumn{1}{c}{ Developing Countries } \\
\hline \multicolumn{1}{c|}{ Country } & Number of Firms & $\begin{array}{c}\text { Number of } \\
\text { International Firms }\end{array}$ & $\begin{array}{c}\text { Number of } \\
\text { Domestic Firms }\end{array}$ \\
\hline 67 & Slovak Republic & 471 & 2 & 469 \\
68 & Slovenia & 30 & 2 & 28 \\
69 & South Africa & 745 & 77 & 668 \\
70 & Sri Lanka & 240 & 1 & 239 \\
71 & Swaziland & 7 & - & 7 \\
72 & Tanzania & 4 & - & 4 \\
73 & Thailand & 411 & 19 & 392 \\
74 & Trinidad and Tobago & 28 & 1 & 27 \\
75 & Tunisia & 45 & 1 & 44 \\
76 & Turkey & 303 & 18 & 285 \\
77 & Ukraine & 138 & 13 & 125 \\
78 & Uruguay & 17 & - & 17 \\
79 & Uzbekistan & 4 & - & 4 \\
80 & Venezuela & 103 & 16 & 87 \\
81 & Zambia & 9 & - & 9 \\
82 & Zimbabwe & 75 & 5 & 70 \\
& & & & $\mathbf{2 3 9 1 0}$ \\
\hline
\end{tabular}

\begin{tabular}{|c|c|c|c|c|}
\hline \multicolumn{5}{|c|}{ Developed Countries } \\
\hline & Country & Number of Firms & \begin{tabular}{|c|} 
Number of \\
International Firms
\end{tabular} & $\begin{array}{c}\text { Number of } \\
\text { Domestic Firms }\end{array}$ \\
\hline 1 & Australia & 1,366 & 149 & 1,217 \\
\hline 2 & Austria & 129 & 32 & 97 \\
\hline 3 & Belgium & 195 & 23 & 172 \\
\hline 4 & Bermuda & 22 & - & 22 \\
\hline 5 & Canada & 1,668 & 212 & 1,456 \\
\hline 6 & Cayman Islands & 1 & - & 1 \\
\hline 7 & Cyprus & 60 & - & 60 \\
\hline 8 & Denmark & 248 & 15 & 233 \\
\hline 9 & Finland & 174 & 27 & 147 \\
\hline 10 & France & 1,048 & 80 & 968 \\
\hline 11 & Germany & 994 & 61 & 933 \\
\hline 12 & Hong Kong & 859 & 142 & 717 \\
\hline 13 & Iceland & 64 & - & 64 \\
\hline 14 & Ireland & 147 & 63 & 84 \\
\hline 15 & Israel & 769 & 125 & 644 \\
\hline 16 & Italy & 318 & 48 & 270 \\
\hline 17 & Japan & 2,632 & 162 & 2,470 \\
\hline 18 & Kuwait & 76 & - & 76 \\
\hline 19 & Luxembourg & 79 & 28 & 51 \\
\hline 20 & Netherlands & 309 & 97 & 212 \\
\hline 21 & New Zealand & 139 & 15 & 124 \\
\hline 22 & Norway & 227 & 32 & 195 \\
\hline 23 & Qatar & 21 & - & 21 \\
\hline 24 & Singapore & 384 & 29 & 355 \\
\hline 25 & Spain & 745 & 27 & 718 \\
\hline 26 & Sweden & 322 & 45 & 277 \\
\hline 27 & Switzerland & 279 & 40 & 239 \\
\hline 28 & Taiwan & 505 & 43 & 462 \\
\hline \multirow[t]{2}{*}{29} & United Arab Emirates & 53 & - & 53 \\
\hline & Total & 14,718 & 1,657 & 13,061 \\
\hline velo & g and Developed Cour & 39,517 & 2,546 & 36,971 \\
\hline
\end{tabular}




\section{Appendix Table 3}

Industry Classification

This table shows the distribution of the firms used in the regressions among the different sectors. It also shows the number of international firms as a percentage of the total number of firms in that sector and the number of international firms from a specific sector as a percentage of the total number of international firms. The table shows these data for all firms in the sample, as well as dividing countries according to their income level. The sample includes only those countries used in the regressions. The United States and the United Kingdom are not included in the sample due to their classification as international financial centers. International firms are those identified as having at least one active depositary receipt program, having raised equity capital in international markets, or being listed on the London Stock Exchange, NASDAQ, or NYSE. Countries are divided by income level following the classification of the World Development Indicators, World Bank at the beginning of the sample period (1989).

\begin{tabular}{|c|c|c|c|c|c|c|c|c|c|}
\hline \multirow[b]{2}{*}{ Industry Classification } & \multicolumn{3}{|c|}{ All Countries } & \multicolumn{3}{|c|}{ Developed Countries } & \multicolumn{3}{|c|}{ Developing Countries } \\
\hline & $\begin{array}{c}\text { Number of } \\
\text { Firms }\end{array}$ & $\begin{array}{l}\text { Percent of } \\
\text { International } \\
\text { Firms in the } \\
\text { Sector }\end{array}$ & $\begin{array}{c}\text { Percent of Firms } \\
\text { from the Sector } \\
\text { among International } \\
\text { Firms }\end{array}$ & $\begin{array}{c}\text { Number of } \\
\text { Firms }\end{array}$ & $\begin{array}{l}\text { Percent of } \\
\text { International } \\
\text { Firms in the } \\
\quad \text { Sector }\end{array}$ & $\begin{array}{l}\text { Percent of Firms from } \\
\text { the Sector among } \\
\text { International Firms }\end{array}$ & $\begin{array}{c}\text { Number of } \\
\text { Firms }\end{array}$ & $\begin{array}{l}\text { Percent of } \\
\text { International } \\
\text { Firms in the } \\
\text { Sector }\end{array}$ & $\begin{array}{l}\text { Percent of Firms from } \\
\text { the Sector among } \\
\text { International Firms }\end{array}$ \\
\hline Agriculture, Forestry, and Fishing & 75 & $2.67 \%$ & $0.40 \%$ & 29 & $3.45 \%$ & $0.35 \%$ & 46 & $2.17 \%$ & $0.47 \%$ \\
\hline Mining & 229 & $15.72 \%$ & $7.19 \%$ & 169 & $16.57 \%$ & $9.79 \%$ & 60 & $13.33 \%$ & $3.72 \%$ \\
\hline Construction & 459 & $4.14 \%$ & $3.79 \%$ & 329 & $3.04 \%$ & $3.50 \%$ & 130 & $6.92 \%$ & $4.19 \%$ \\
\hline Manufacturing & 3,991 & $5.14 \%$ & $40.92 \%$ & 2,745 & $3.90 \%$ & $37.41 \%$ & 1,246 & $7.87 \%$ & $45.58 \%$ \\
\hline Transportation and Public Utilities & 639 & $10.17 \%$ & $12.97 \%$ & 472 & $7.42 \%$ & $12.24 \%$ & 167 & $17.96 \%$ & $13.95 \%$ \\
\hline Wholesale Trade & 601 & $3.83 \%$ & $4.59 \%$ & 512 & $2.93 \%$ & $5.24 \%$ & 89 & $8.99 \%$ & $3.72 \%$ \\
\hline Retail Trade & 436 & $4.36 \%$ & $3.79 \%$ & 367 & $2.72 \%$ & $3.50 \%$ & 69 & $13.04 \%$ & $4.19 \%$ \\
\hline Finance, Insurance, and Real Estate & 1,530 & $5.42 \%$ & $16.57 \%$ & 1,116 & $4.12 \%$ & $16.08 \%$ & 414 & $8.94 \%$ & $17.21 \%$ \\
\hline Services & 563 & $7.10 \%$ & $7.98 \%$ & 461 & $7.38 \%$ & $11.89 \%$ & 102 & $5.88 \%$ & $2.79 \%$ \\
\hline Public Administration & 68 & $13.24 \%$ & $1.80 \%$ & 4 & $0.00 \%$ & $0.00 \%$ & 64 & $14.06 \%$ & $4.19 \%$ \\
\hline Total & 8,591 & $5.83 \%$ & $100.00 \%$ & 6,204 & $4.61 \%$ & $100.00 \%$ & 2,387 & $9.01 \%$ & $100.00 \%$ \\
\hline
\end{tabular}




\section{Appendix Table 4}

\section{Fixed-Effect Country-Level Regressions}

This table reports fixed-effects panel estimates on the relation between country-level variables and the annual share of international firms over total firms in each country. The top panel presents results for the whole sample of countries, while the bottom panel presents results for the developing countries' subsample. International firms are those identified as having at least one active depositary receipt program, having raised equity capital in international markets, or being listed on the London Stock Exchange, NASDAQ, or NYSE. The United States and the United Kingdom are not included in the sample due to their classification as international financial centers. Z-statistics are in brackets. *, **, *** mean significant at ten, five, and one percent, respectively.

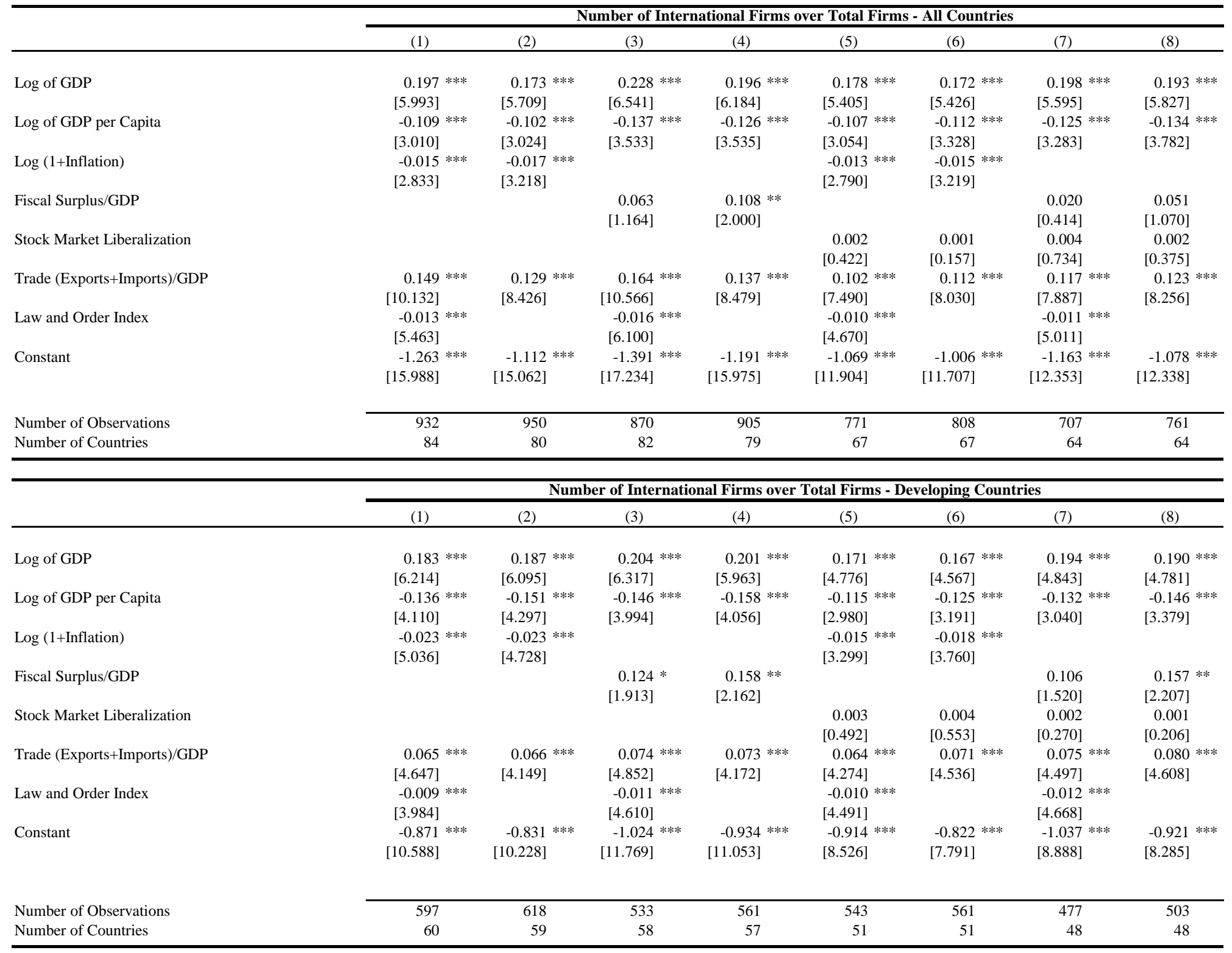

